\title{
A Colegialidade nOS Tribunais: QUANDO UMA IDEOLOGIA VIRA DOGMA E O DOGMA UM PRINCÍPIO*
}

\author{
CARLOS VITOR NASCIMENTO DOS SANTOS ${ }^{\dagger}$
}

RESUMO: O objetivo do presente trabalho foi produzir uma revisão de literatura de modo a destacar possíveis caminhos aos quais a categoria jurídica da colegialidade foi construída nos livros de Direito por autores considerados clássicos até o alcance de uma discussão acerca de sua fundamentação no texto constitucional. O resultado foi a demonstração de como, no discurso jurídico, uma ideia pode virar um dogma e o dogma um princípio constitucional.

PAlAVRAS-ChAVE: Colegialidade nos Tribunais; Ideologia; Princípio Constitucional.

\footnotetext{
ABSTRACT: The objective of this paper was to produce a literature review to show possible ways in which the legal category of collegiality was built in the law in books by classic authors until the reach of the discussion about its substantiation in the constitutional text. The result was a demonstration of how, in legal discourse, an idea can become a

* O texto representa parte de pesquisa realizada no âmbito do Programa de Pósgraduação em Direito da PUC-Rio, integrando a tese "O exercício da colegialidade no Supremo Tribunal Federal: entre a construção social do discurso e as práticas judiciárias". Meus especiais agradecimentos a CAPES pelo fomento da pesquisa e aos meus orientadores: Prof ${ }^{\mathrm{a}}$. Dra. Giselle Cittadino (PUC-Rio) e Prof. Dr. Fernando Fontainha (IESP/RioUERJ). Agradeço ainda pelas valiosas contribuições dos amigos e professores Alexandre Veronese (UnB), Pedro Heitor Barros Geraldo (UFF) e Fábio Leite (PUC-Rio).

† Doutor em Teoria do Estado e Direito Constitucional pela Pontifícia Universidade Católica do Rio de Janeiro (PUC-Rio), Mestre em Direito Constitucional pela Universidade Federal Fluminense (UFF) e Graduado em Direito pela Escola de Direito do Rio de Janeiro da Fundação Getulio Vargas (FGV-Rio).
} 
dogma and dogma can became a constitutional principle.

KEYWORDS: Collegiality in the Courts; Ideology; Constitutional Principle.

\section{SUMÁRIO:}

I. InTROdUÇão: A CONSTRUÇão Da COLEGIALIDADE ENQUANTO CATEGORIA JURÍDICA...........................................................478

II. IDEOLOGIA RECURSAL: A HIERARQUIA CONSTRUÍDA PELO NÚMERO.......................................479

III. O ELO PERDIDO: A ORALIDADE COMO PRINCIPAL FUNDAMENTO DA COLLEGIALITÁ...........................485

IV. O MOMENTO "PORTAS ABERTAS" DO JULGAMENTO COLEGIADO: A DISCUSSÃo ORAL Do MÉRITO DA CAUSA ........................................492

V. QUEM DECIDIU? A DELIBERAÇÃO SECRETA COMO GARANTIA DO MAGISTRADO .....................................................495

VI. ORGANIZANDO A FORÇA DE TRABALHO: os MEMbros do COLEGIAdo e os ÓRGãos JULGadores............499

VII. A REIVINDICAÇão DOS JURISTAS à Constitucionalização do Processo Civil .............................505

VIII.A MOVIMENTAÇÃO DOUTRINÁRIA PELA APROPRIAÇÃ̃O DO DISCURSO CONSTITUCIONAL .......................511

IX. CONSIDERações finaIS: QUANDO A IDEOLOGIA VIRA DOGMA E O DOGMA UM PRINCÍPIO....515

X. REFERÊNCIAS.........................................................................................518 


\section{TABLE OF CONTENTS:}

I. INTRODUCTION: THE CONSTRUCTION OF COLLEGIALITY AS A LEGAL CATEGORY.

II. APPEALING IDEOLOGY: THE HIERARCHY BUILT BY THE NUMBER .....................................479

III. THE LOST ELO: ORALITY AS THE MAIN FOUNDATION OF COLLEGIALITÀ.................485

IV. THE "OPEN DOORS" MOMENT OF THE COLLEGED JUDGMENT: THE ORAL DISCUSSION OF THE MERITUM CAUSAE.......................492

V. WHO DECIDED? SECRET DELIBERATION AS GUARANTEE OF THE JUDGE. .495

VI. ORGANIZING THE WORKFORCE: THE MEMBERS OF THE COLLEGE AND THE JUDICIAL BODIES.......499

VII. THE CLAIM OF JURISTS to the Constitutionalization of the Civil Process............505

VIII.THE DOCTRINAL MOVIMENT FOR THE APPROPRIATION OF THE CONSTITUTIONAL DISCOURSE .511

IX. FINAL CONSIDERATIONS: WHEN IDEOLOGY BECOMES DOGMA AND THE DOGMA BECOMES A PRINCIPLE .........................................515

X. REFERENCES ...............................................................518 


\section{INTRODUÇÃO: A CONSTRUÇÃO DA COLEGIALIDADE ENQUANTO CATEGORIA JURÍDICA}

A colegialidade nos tribunais do Brasil é um tema pouco explorado tanto na doutrina clássica quanto na mais recente do direito brasileiro. $\mathrm{O}$ debate que tramita em torno da categoria está ainda muito difuso, o que gerou dificuldade em mapear uma discussão mais detalhada e sistemática a seu respeito. A partir da pouca profundidade do debate, optou-se por uma busca bibliográfica em fontes de pesquisa confiáveis e cada vez mais utilizadas por pesquisadores principalmente das ciências sociais ${ }^{1}$, como as bases de dados online disponíveis pelos sites da BDTD, periódico da CAPES e SCIELO. Nos sites indicados, foi feita uma busca apenas pela categoria "colegialidade", por ser considerada mais ampla e permitir o acesso a uma diversidade maior de textos.

Nos textos encontrados, houve uma prevalência de referências à colegialidade enquanto um órgão da universidade, em que professores se reuniam para discutir e deliberar sobre temas afins. Os textos que se referiam à colegialidade nos tribunais eram minorias e sempre como citações e subtópicos a partir do debate travado pela doutrina brasileira acerca do agravo interno e a suposta supressão da colegialidade. Percebido e mapeado o debate travado pela doutrina mais recente, foi feita uma investigação dos autores citados nestes textos que faziam menção à colegialidade. E alguns fenômenos foram observados: a colegialidade enquanto categoria jurídica é pouco discutida em artigos publicados em periódicos; os autores contemporâneos que fazem menção ao tema citam frequentemente uns aos outros; e apenas Pontes de Miranda era citado pelos autores mais recentes como referência à doutrina clássica do processo civil brasileiro.

As observações acima estimularam uma ampliação da pesquisa sobre a colegialidade nos livros citados como referência bibliográfica pelos autores mapeados: "comentários ao código de processo civil", "código de processo civil interpretado", manuais de direito processual civil, "teoria do processo civil brasileiro", dentre outros. Pesquisando em tais lugares, foi possível ter acesso aos livros que faziam menção à colegialidade e que também eram citados pela doutrina mais recente do processo civil

${ }^{1}$ Cf. FONTAINHA, Fernando; HARTMANN, Ivar; CORREAA, Ana Maria Macedo; ALVES, Camila; PITASSE, Katarina. Metodologia da Pesquisa. Rio de Janeiro, RJ: FGV Direito RIO, 2014, p. 31-35. Disponível em:

$<$ https://direitorio.fgv.br/sites/direitorio.fgv.br/files/u100/tcc metodologia da pesquisa 2014-2.pdf >. Acesso em: 09 de agosto de 2017. 
brasileiro, além do livro em que Pontes de Miranda é citado como única referência à doutrina clássica sobre o tema no Brasil. Constituiu-se, assim, duas ordens de pesquisa: uma referente ao mapeamento da doutrina clássica, por acesso ao texto de Pontes de Miranda; e outra sobre como a doutrina mais recente no Brasil que reivindica a categoria pesquisada.

A partir do acesso à bibliografia inicial, optei por seguir uma sequência cronológica em que fosse possível, além de analisar textos e autores, contextualizá-los a possíveis eventos ocorridos à época dos escritos. Deste modo, foi realizada uma revisão de literatura destacando caminhos aos quais a categoria jurídica da colegialidade foi construída nos livros de Direito por autores considerados clássicos até o alcance de uma discussão acerca de sua fundamentação no texto constitucional, o que poderá ser mais bem compreendido a partir das páginas seguintes.

\section{IDEOLOGIA RECURSAL: A HIERARQUIA CONSTRUÍDA PELO NÚMERO}

O processo civil no Brasil, até o começo do século XX era discutido de forma muito difusa. Primeiro por existir controvérsias a respeito do que se considerava direito processual e material e, depois, pela autonomia dada aos Estados-membros para criar suas próprias leis processuais. ${ }^{2}$ Dentre outras questões, essas estimulavam a criação de movimentos em prol da unificação das leis processuais civis, como o feito pelo Congresso Nacional no final do século XIX. Pontes de Miranda ${ }^{3}$ associa estes fenômenos à baixa quantidade de estudos que sistematizassem o processo civil brasileiro até a primeira metade do século $\mathrm{XX}^{4}$, quando é editado o Decreto-Lei $n^{0}$ 1.608/1939, que determina já em seu art. $1^{0}$ que "O processo civil e comercial, em todo o território brasileiro, reger-se-á por este código, salvo o dos feitos por ele não regulados, que constituam objeto de lei especial".

E com a criação do primeiro código de processo civil que abrangesse as leis processuais do país, é dado início à publicação em série de textos

${ }^{2}$ Cf. PONTES DE MIRANDA. Comentários ao Código de Processo Civil, Tomo I. Rio de Janeiro, RJ: Forense, 1947.

${ }^{3}$ Cf. PONTES DE MIRANDA. Comentários ao Código de Processo Civil, Tomo I. Rio de Janeiro, RJ: Forense, 1947.

${ }^{4} \mathrm{O}$ mesmo destaque já havia sido feito por Teixeira de Freitas quando publicou sua obra que discutia sistematicamente as leis civis brasileiras.Cf. TEIXEIRA DE FREITAS, Augusto. Consolidação das Leis Civis. 3ª̣ ed. Rio de Janeiro, RJ: B. L. Garnier, 1876. 
capazes de apresentar reflexões, esclarecimentos e, sobretudo, fundamentos ao processo civil brasileiro. As obras consultadas apresentam uma mesma estrutura: os livros são organizados a partir da sequência de temas e artigos dispostos no código de processo civil brasileiro. A estruturação dos livros sobre processo civil escritos após o marco normativo permitiu a identificação do tema investigado colegialidade - sempre associado ao sistema recursal, dando o primeiro indicativo de compreensão da categoria em análise. Os passos seguintes à análise podem ser resumidos à leitura dos textos escritos por autores da rede identificada anteriormente como compondo a doutrina clássica brasileira sobre o tema, além da reconstrução e compreensão do debate que tramitava em torno da colegialidade, organizado a partir de uma sequência cronológica de publicação.

Assim, com a publicação de Comentários ao Código de Processo Civil primeira obra escrita sobre o tema -, em 1940, por Plácido e Silva, é apresentado como justificativa da existência do recurso a possibilidade de correção de sentenças proferidas pelo juiz. ${ }^{5} \mathrm{~A}$ sinalização de elementos fundamentais à compreensão da colegialidade nos tribunais do Brasil, apontados pela doutrina clássica se resumem a correção de sentenças e a existência de uma instância mais alta que a do juiz que as proferiu. ${ }^{6} \mathrm{~A}$ correção das sentenças poderá ser pleiteada por aquele que manifestar o seu inconformismo via recurso, sob a alegação de suposta violações a direitos decorrentes de erros proferidos pelo juiz singular. ${ }^{7} \mathrm{E}$ o elemento seguinte aponta à existência de uma hierarquia de jurisdição, onde o juiz singular analisa e julga questões em primeira instância e o tribunal o faz em segunda instância (chamada também de instância recursal por Plácido e Silva ${ }^{8}$.

Neste primeiro momento de análise, a categoria "recurso" surge como fundamental à imersão no debate que permitirá compreender a colegialidade enquanto categoria jurídica reivindicada pela doutrina clássica brasileira do processo civil. Por seu intermédio, foi possível dar um salto à discussão para investigar tanto o fundamento do recurso

${ }^{5}$ Cf. DE PLACIDO E SILVA. Comentários ao Código de Processo Civil. Curitiba, PR:

Guaíra, 1940.

${ }^{6}$ DE PLACIDO E SILVA. Comentários ao Código de Processo Civil. Curitiba, PR: Guaíra, 1940, p. 541.

7 AMARAL, Oswaldo Pinto do. Código de Processo Civil Brasileiro Comentado, Volume V: Arts. 808 a 1052. São Paulo, SP: Livraria Acadêmica/Saraiva \& Cia Editores, 1941, p. 13-15.

${ }^{8}$ Cf. DE PLACIDO E SILVA. Comentários ao Código de Processo Civil. Curitiba, PR: Guaíra, 1940. 
quanto essa possível hierarquia na jurisdição brasileira, questões também discutidas por Carvalho Santos. ${ }^{9}$ Assim como Plácido e Silva e Oswaldo Pinto do Amaral, Carvalho Santos concorda que a justificativa de existência do recurso seja o erro cometido pelo juiz singular ao proferir sentenças, sob o fundamento da possibilidade de seres humanos cometerem falhas. ${ }^{10} \mathrm{O}$ que pode associar a categoria "recurso" a um mecanismo de correção de tais falhas, sob um fundamento não jurídico, sem qualquer tipo de referência e desenvolvido sem maiores preocupações metodológicas ou epistemológicas. A aproximação de tal fundamento, então, a um sentimento ou ideia torna-se inevitável. No entanto, esse fundamento é construído e compartilhado pela doutrina clássica brasileira, reproduzindo-o em todos os seus escritos sobre o tema.

A partir da compreensão de que o recurso deve ser utilizado para corrigir falhas do juiz de primeira instância, algumas outras questões se insurgem, como a identificação dos elementos necessários e caracterizadores àquele que possui competência para proceder a tais correções. Carvalho Santos, por exemplo, apresenta importante elemento a ser analisado por essa construção doutrinária: a pluralidade de julgadores que compõe o tribunal competente para corrigir falhas deixadas pelo juiz de primeira instância. Isto é, além da já sinalizada hierarquia na jurisdição, a doutrina se atenta também à pluralidade de julgadores que compõem o tribunal. ${ }^{11}$

Ao se referir à pluralidade de julgadores, Carvalho Santos destaca que assim como a hierarquia, tais elementos são fundamentais à caracterização do tribunal. ${ }^{12}$ Destacando-se o fato de que, de acordo com as palavras do autor, a hierarquia do tribunal sobre o juiz de primeira instância pode ocorrer das maiores experiências, estudos e conhecimentos jurídicos que os membros do tribunal acumulam em comparação ao juiz de primeira instância, o que decorre da pluralidade de julgadores. Isto é, a pluralidade de membros reapreciando uma

${ }^{9}$ CARVALHO SANTOS, João Manuel de. Código de Processo Civil Interpretado, Volume IX. Rio de Janeiro, RJ: Freitas Bastos, 1941, p. 200-201.

${ }^{10}$ Cf. DE PLACIDO E SILVA. Comentários ao Código de Processo Civil. Curitiba, PR: Guaíra, 1940; AMARAL, Oswaldo Pinto do. Código de Processo Civil Brasileiro

Comentado, Volume V: Arts. 808 a 1052. São Paulo, SP: Livraria Acadêmica/Saraiva \& Cia Editores, 1941; e CARVALHO SANTOS, João Manuel de. Código de Processo Civil Interpretado, Volume IX. Rio de Janeiro, RJ: Freitas Bastos, 1941.

${ }^{11}$ CARVALHO SANTOS, João Manuel de. Código de Processo Civil Interpretado, Volume IX. Rio de Janeiro, RJ: Freitas Bastos, 1941, p. 202.

${ }^{12}$ Cf. CARVALHO SANTOS, João Manuel de. Código de Processo Civil Interpretado, Volume IX. Rio de Janeiro, RJ: Freitas Bastos, 1941. 
questão anteriormente analisada por um juiz singular, ou por um número inferior de julgadores, permitiria uma apreciação mais cuidadosa do caso, diminuindo as chances de ocorrer erros de julgamento capazes de não reconhecer, suprimir ou violar direitos e garantias.

Outra fundamentação atribuída ao tribunal é o de a pluralidade de julgadores assegurar um fim democrático à decisão, permitindo que prevaleça o entendimento de uma maioria em detrimento da minoria, conforme palavras de Jorge Americano. ${ }^{13} \mathrm{E}$ além de fundamentação diversa, e também defender a existência de uma hierarquia entre tribunal e juiz singular, o autor acima apresenta uma nova categoria como forma de qualificar o órgão julgador em segunda instância a partir das características que possui, chamando-o de tribunal colegial. Dentre os textos mapeados e qualificados como compondo uma doutrina clássica brasileira de direito processual, é a primeira vez que a expressão aparece. Essa construção doutrinária da colegialidade nos tribunais como decorrente do sistema recursal é algo que se mantém nos textos escritos à época, permitindo inclusive uma consolidação do uso da categoria pelos juristas brasileiros após a frequência de sua utilização para fazer referência ao órgão julgador de segunda instância.

Todas as questões identificadas devem nos atentar às fundamentações dessas importantes categorias apropriadas pelo direito processual brasileiro que, conforme será visto adiante, reivindica ser oriundo ou sofrer influências do direito italiano. Mas que, por meio de simples análise como a aqui proposta, nos remete a características bem peculiares ao sistema jurídico brasileiro, como atribuir justificação a determinados modelos a partir de sentimentos ou ideias. $O$ que estimula uma ideologização do sistema recursal capaz de fundamentar a colegialidade do tribunal em critérios nada científicos e não jurídicos, como a hierarquia e o número de julgadores, conforme mencionado acima por Jorge Americano. ${ }^{14}$

Mais adiante, com a publicação da obra de João Monteiro, em 1956, surge uma discussão mais densa sobre a importação de alguns modelos do direito italiano e a sua apropriação pelo direito brasileiro. ${ }^{15}$ Além de

${ }^{13}$ AMERICANO, Jorge. Comentários ao Código de Processo Civil do Brasil, Volume IV. São Paulo, SP: Livraria Acadêmica/Saraiva \& Cia Editores, 1943, p. 8.

${ }^{14}$ Cf. AMERICANO, Jorge. Comentários ao Código de Processo Civil do Brasil, Volume IV. São Paulo, SP: Livraria Acadêmica/Saraiva \& Cia Editores, 1943.

${ }^{15}$ Cf. MONTEIRO, João. Teoria do Processo Civil, Vol. II. $6^{\underline{a}}$ ed. Rio de Janeiro, RJ: Borsoi, 1956. 
concordar que o sistema de recursos decorre da fragilidade humana ${ }^{16} \mathrm{e}$ pode ser considerado como "remédio contra injustiças e erros de sentença"17, o autor afirma que ele é oriundo do duplo grau de jurisdição do sistema jurídico italiano. Destacando ainda que, na Itália, o sistema recursal é exceção e, no direito brasileiro, a ideia da falibilidade humana que o fundamenta estaria transformando o recurso em regra, o que implica em maior despesa e tempo de apreciação das demandas. ${ }^{18} \mathrm{~A}$ observação de João Monteiro sobre os sistemas jurídico italiano e brasileiro nos remete a um olhar mais atento acerca da possibilidade de o fundamento do sistema recursal e colegialidade nos tribunais não ser o mesmo em Brasil e Itália, embora a doutrina clássica afirme que o primeiro decorre do segundo. ${ }^{19}$

O diálogo estabelecido com o direito italiano por João Monteiro, inclusive por meio da citação frequente a textos de Mortara e Chiovenda, desperta elogios de Pontes de Miranda, que concorda com o autor ao reafirmar as origens do direito processual civil brasileiro. ${ }^{20}$ Pontes de Miranda, então, continua a estabelecer diálogos com a doutrina italiana do processo civil por meio principalmente de citações a Chiovenda, embora tenha destacado que professores lusitanos influenciaram de sobremaneira os seus escritos tanto pela convivência que tiveram quanto à orientação dada ao direito brasileiro na regência de suas leis processuais durante o século XIX. ${ }^{21}$ Possivelmente a influência, e os estudos acerca do direito processual civil italiano, contribuíram à importação ao direito brasileiro de uma categoria jurídica fundamental ao duplo grau de jurisdição italiano: a colegialidade. $\mathrm{O}$ processo iniciado aparentemente

${ }^{16}$ MONTEIRO, João. Teoria do Processo Civil, Vol. II. $6^{\text {a }}$ ed. Rio de Janeiro, RJ: Borsoi, 1956, p. 606.

17 MONTEIRO, João. Teoria do Processo Civil, Vol. II. $6^{a}$ ed. Rio de Janeiro, RJ: Borsoi, 1956, p. 621.

${ }^{18}$ MONTEIRO, João. Teoria do Processo Civil, Vol. II. $6^{\mathrm{a}}$ ed. Rio de Janeiro, RJ: Borsoi, 1956, p. 607.

${ }^{19}$ Cf. MONTEIRO, João. Teoria do Processo Civil, Vol. II. $6^{a}$ ed. Rio de Janeiro, RJ:

Borsoi, 1956.

${ }^{20}$ Cf. MONTEIRO, João. Teoria do Processo Civil, Vol. II. $6^{a}$ ed. Rio de Janeiro, RJ:

Borsoi, 1956; MORTARA, Lodovico. Manuale della Procedura Civile, Volume 1. $5^{\text {a }}$

ed. Torino: Unione Tipografico-Editrice, 1906; CHIOVENDA, Guiseppe. Principii di

Diritto Processuale Civile: le azioni, il processo di cognizione. $3^{\underline{a}}$ ed. Napoli: N. Jovene, 1923; e PONTES DE MIRANDA. Comentários ao Código de Processo Civil, Tomo I. Rio de Janeiro, RJ: Forense, 1947, p. xiv.

${ }^{21}$ Cf. PONTES DE MIRANDA. Comentários ao Código de Processo Civil, Tomo I. Rio de Janeiro, RJ: Forense, 1947. 
por Jorge Americano e consolidado por Pontes de Miranda tornou-se referência ao tribunal de segunda instância, sendo utilizado atualmente para qualificar o órgão julgador, como se um sinônimo fosse. ${ }^{22}$

Com a publicação de os Comentários ao Código de Processo Civil, em 1958 (Tomo I) e 1960 (Tomo II), Pontes de Miranda consolida a colegialidade como uma categoria jurídica própria ao sistema recursal brasileiro, capaz de se referir ao tribunal composto por uma pluralidade de julgadores, e corrobora o fundamento de ser hierarquicamente superior ao juiz singular devido a própria pluralidade de membros do órgão julgador. ${ }^{23}$ A colegialidade, então, passa a ser comumente utilizada pelo direito brasileiro para se referir aos tribunais que compõem tanto a segunda instância julgadora quanto os próprios tribunais superiores, o que será mais bem notado quando da análise da doutrina brasileira mais recente do processo civil, nas páginas seguintes.

Todo o processo de construção, reivindicação e consolidação da categoria jurídica em análise não seguiu um fluxo linear e contínuo. Ele partiu de uma ideia que, por sua repetição, constância e nível de elaboração, foi ganhando cada vez mais adeptos até se tornar compartilhável na comunidade jurídica. Assegurar o fim político, atribuir um caráter democrático, pôr fim às injustiças, corrigir falhas humanas são todos fundamentos metajurídicos que ganharam força, não apenas se consolidando entre os juristas, mas atribuindo sentido a determinadas categorias qualificadas pela doutrina como jurídicas. O processo de atribuição de sentidos e fundamentação de tais categorias jurídicas permitiu a identificação de um caráter predominantemente ideológico do sistema recursal brasileiro.

Essa ideologia recursal fundada no número, na pluralidade de julgadores, é a primeira fonte orientadora da colegialidade enquanto uma categoria jurídica. O que significa dizer que pode existir um sistema de qualificação de categorias ou mesmo de categorização baseado numa ideologia própria dos juristas, como a colegialidade, fundada na ideia de que o número de membros que atribui um caráter plural ao órgão julgador de segunda instância produz uma hierarquia sobre o juiz

${ }^{22}$ Cf. AMERICANO, Jorge. Comentários ao Código de Processo Civil do Brasil, Volume IV. São Paulo, SP: Livraria Acadêmica/Saraiva \& Cia Editores, 1943; PONTES DE MIRANDA. Comentários ao Código de Processo Civil, Tomo I. $2^{\mathrm{a}}$ ed. Rio de Janeiro, RJ: Forense, 1958; e PONTES DE MIRANDA. Comentários ao Código de Processo Civil, Tomo II. $2^{\mathrm{a}}$ ed. Rio de Janeiro, RJ: Forense, 1960.

${ }^{23}$ Cf. PONTES DE MIRANDA. Comentários ao Código de Processo Civil, Tomo I. $2^{\mathrm{a}}$ ed. Rio de Janeiro, RJ: Forense, 1958; e PONTES DE MIRANDA. Comentários ao

Código de Processo Civil, Tomo II. $2^{a}$ ed. Rio de Janeiro, RJ: Forense, 1960. 
singular. Ideia que se aproxima inclusive do brocardo "a união faz a força". Isto é, a reunião de diferentes julgadores, capazes de acumular diferentes experiências e conhecimentos, produz um status de superioridade sobre um número inferior de julgadores. Em um primeiro momento, o número produziria uma hierarquia e, posteriormente, uma aparência de maior proximidade com a verdade jurídica a partir de novos elementos surgidos a partir da colegialidade: a discussão e deliberação. O duplo status criado pela colegialidade - maior hierarquia e qualificação do órgão julgador de segunda instância -, no entanto, pode ser aparente, ou melhor, relativizado.

Isso porque, por ter sido uma categoria importada do direito processual civil italiano, é possível que o direito brasileiro tenha se apropriado de tal categoria sob fundamentação diversa, conforme denunciado por João Monteiro. ${ }^{24} \mathrm{O}$ que nos aponta à necessidade do estabelecimento de um diálogo maior com a doutrina processual civil italiana, com vistas a compreender o uso e fundamentação da colegialidade em seu sistema jurídico. E a sua consequente apropriação pelo direito brasileiro, que reivindica por meios de autores anteriormente citados uma proximidade entre os sistemas jurídicos, tema que será mais bem discutido no tópico seguinte.

\section{O ELO PERDIDO: A ORALIDADE COMO PRINCIPAL FUNDAMENTO DA COLLEGIALITÁ}

O tópico anterior tentou destacar aspectos importantes apontados pela doutrina clássica do processo civil brasileiro no que se refere à categoria jurídica da colegialidade. E uma das questões surgidas no debate foi o estabelecimento de uma relação de proximidade reivindicada pela doutrina clássica do processo civil brasileiro com a doutrina italiana do processo civil. Conforme visto anteriormente, vários autores brasileiros recorrem à doutrina italiana para fundamentar a categoria da colegialidade, pressupondo esta proximidade entre os sistemas jurídicos vigentes em Brasil e Itália, ao menos em relação ao processo civil. O que demonstrou a necessidade de se atribuir um olhar mais atento também à doutrina italiana sobre o tema.

Entretanto, a rede de autores clássicos brasileiros identificada anteriormente cita poucos autores italianos em seus textos, referindo-se

${ }^{24}$ Cf. MONTEIRO, João. Teoria do Processo Civil, Vol. II. $6^{a}$ ed. Rio de Janeiro, RJ: Borsoi, 1956.

3 JOURNAL OF INSTITUTIONAL STUDIES 1 (2017) 
bastante à "doutrina italiana", sem citar os autores correspondentes. Ou até mesmo citam alguns autores sem fazer referência ao texto de onde a ideia foi retirada. Essas ausências de informações dificultaram a recorribilidade aos autores mencionados e seus respectivos textos. Então, adotou-se o seguinte procedimento de pesquisa: primeiramente, foram pesquisados os autores mencionados pela doutrina clássica brasileira com referência (apenas Guiseppe Chiovenda). Após, foi feito um mapeamento de quais autores italianos eram mencionados por autores brasileiros sem qualquer referência (Guiseppe Chiovenda, Lodovico Mortara e Ulpiano). Assim, foi possível mapear, ainda que de forma inicial, que autores poderiam ter influenciado a doutrina clássica brasileira a partir da construção feita pela própria doutrina, atribuindo destaque ao fato de que todos os autores italianos até agora mencionados escreveram e publicaram suas obras antes do primeiro livro aqui citado como compondo a já mencionada rede de autores clássicos brasileiros do processo civil.

Em um segundo momento, recorreu-se a Guiseppe Chiovenda, único autor citado com referências aos seus textos por vários autores brasileiros, para verificar com quem ele dialogava quando se referia à colegialidade, permitindo o alcance à obra de Lodovico Mortara em que a colegialidade também é discutida. ${ }^{25}$ Posteriormente, foi consultada a obra de Enrico Tullio Liebman, que foi aluno de Chiovenda e tornou-se conhecido no direito brasileiro após a sua chegada a São Paulo, em 1941. ${ }^{26}$ Por meio da obra de Liebman, foi possível alcançar a de Enrico Redenti, que também discutia a colegialidade enquanto categoria jurídica, além de destacar seu fundamento e características. ${ }^{27} \mathrm{~A}$ partir daí, foram consultadas algumas obras italianas posteriores que poderiam versar sobre o mesmo tema, principalmente para identificar alguma mudança ou manutenção da discussão, como: Mauro Cappelletti, Crisanto Mandrioli, e Luigi Montesano e Giovanni Arieta. ${ }^{28}$ Além de outros autores que não são

${ }^{25}$ Cf. CHIOVENDA, Guiseppe. Principii di Diritto Processuale Civile: le azioni, il processo di cognizione. $3^{3}$ ed. Napoli: N. Jovene, 1923; e MORTARA, Lodovico. Manuale della Procedura Civile, Volume 1. $5^{\underline{a}} \mathrm{ed}$. Torino: Unione TipograficoEditrice, 1906.

${ }^{26}$ Cf. LIEBMAN, Enrico Tullio. Manuale di Diritto Processuale Civile, Volume II. Milano: Giuffrè, 1959.

${ }^{27}$ Cf. REDENTI, Enrico. Derecho Procesal Civil, Tomo I. Trad. Santiago Sentis Melendo e Marino Ayerra Redin. Buenos Aires: Ediciones Juridicas Europa-America, 1957.

${ }^{28}$ Cf. CAPPELLETTI, Mauro. Processo e Ideologie. 2aa ed. Bologna: Il Mulino Editrice, 1969; MANDRIOLI, Crisanto. Corso di Diritto Processuale Civile, 2: Il Processo di 
italianos, mas se referem à doutrina italiana em seus textos, explicando alguns procedimentos em seu sistema jurídico italiano, como: Mario Casarino Viterbo e José Becerra Bautista. ${ }^{29}$

Sendo referência dos autores mapeados anteriormente, e que compõem a doutrina clássica brasileira do direito processual civil, Guiseppe Chiovenda apresenta a seguinte definição à colegialidade: "L'attività del singolo, o del collegio chiamato a personificare la magistratura, è attività della magistratura. In particolare il collegio è organo della magistratura collegiale: esso agisce come unità distinta dalle persone dei suoi componenti"..$^{30}$

A definição acima, apesar de curta, apresenta questões fundamentais à compreensão da colegialidade. A primeira delas refere-se ao exercício de funções e competências características do Poder Judiciário, principalmente por ser um órgão que o compõe. A segunda estabelece uma distinção entre o órgão e os membros que compõem o órgão. Isto é, para Chiovenda deve existir uma dissociação entre o órgão colegiado e os membros do colegiado. ${ }^{31}$ Considerando a organização do Poder Judiciário em diversos órgãos jurisdicionais, responsáveis por apreciar demandas que lhes são distribuídas de acordo com a competência de cada órgão, o membro do órgão colegiado considerado de forma isolada não estaria investido da competência jurisdicional, apenas o órgão colegiado estaria. Essa distinção é fundamental para esclarecer que, no direito processual civil italiano, os membros do órgão colegiado não proferem decisões, apenas quem o faz é o órgão colegiado.

Ainda sobre a organização do Poder Judiciário, Chiovenda inicialmente afasta a ideia de que a pluralidade nos e dos tribunais gera uma hierarquia entre os órgãos jurisdicionais..$^{32}$ Para o autor, a hierarquia envolveria uma dependência de um órgão sobre outro, e o que há é uma divisão de competências. Logo, a pluralidade nos e dos tribunais deve se

Cognizone. Torino: G. Giappichelli, 1975; e MONTESANO, Luigi; ARIETA, Giovanni. Diritto Processuale Civile, 2: La Cognizione di Rito Ordinario. Torino: G. Giappichelli, 1994.

${ }^{29}$ Cf. VITERBO, Mario Casarino. Manual de Derecho Procesal: Derecho Procesal

Orgánico, Tomo II. $2^{\mathrm{a}}$ ed. Santiago: Editorial Jurídica de Chile, 1970; e BAUTISTA, José Becerra. El Proceso Civil em México. 4ª ed. Ciudad del México: Editorial Porrúa, 1974. ${ }^{30}$ CHIOVENDA, Guiseppe. Principii di Diritto Processuale Civile: le azioni, il processo di cognizione. $3^{\mathrm{a}}$ ed. Napoli: N. Jovene, 1923, p. 406.

${ }^{31}$ Cf. CHIOVENDA, Guiseppe. Principii di Diritto Processuale Civile: le azioni, il processo di cognizione. $3^{\mathrm{a}}$ ed. Napoli: N. Jovene, 1923.

${ }^{32}$ Cf. CHIOVENDA, Guiseppe. Principii di Diritto Processuale Civile: le azioni, il processo di cognizione. $3^{\underline{a}}$ ed. Napoli: N. Jovene, 1923. 
relacionar a uma forma de administração e organização do Poder Judiciário. ${ }^{33}$

Contrariando a ideia do direito brasileiro de que a pluralidade de julgadores gera uma hierarquia entre os órgãos jurisdicionais, algumas questões começam a ganhar destaque: o sistema jurídico brasileiro, por meio de autores clássicos do direito processual civil, alega ter proximidade com o sistema jurídico italiano, importando a regra da colegialidade. No entanto, o direito brasileiro o faz sob fundamentação diversa, gerando dúvidas acerca da importação também de seus elementos caracterizadores. Para compreender o que aproxima e distancia o sistema processual civil brasileiro do italiano, é necessário também conhecer alguns de seus procedimentos específicos, capaz de identificar o fundamento da colegialidade no direito italiano.

E em relação à organização das dinâmicas ocorridas no órgão colegiado, Liebman descreve minimamente alguns de seus procedimentos ${ }^{34}$, destacando que causas mais complexas são apreciadas principalmente pelo colegiado, que o faz de forma solene por se tratar de uma audiência em que vários atores do processo estão presentes para discutir a causa em toda a sua complexidade, o que sugere uma organização necessária da dinâmica. Nesta sessão de julgamento, em que estão presentes as partes e os membros do colegiado, o objetivo é a discussão do caso. Isto é, na sessão de julgamento do colegiado é estabelecido um diálogo entre partes e membros do colegiado a partir da apresentação das razões de seus posicionamentos, que pode ser feita de forma oral ou escrita, além de possíveis esclarecimentos requeridos pelo colegiado. Além disso, Liebman destaca duas outras questões: (i) a discussão do mérito da causa de forma presencial e (ii) uma organização das dinâmicas e interações ali ocorridas, que será melhor discutida em tópico específico. ${ }^{35}$

A discussão do mérito da causa é mencionada por Mortara, primeiro autor italiano que se refere à colegialidade nos textos acessados, ao discutir a colegialidade. ${ }^{36} \mathrm{O}$ autor se refere à colegialidade para fazer menção à audiência ocorrida no tribunal, após a sucumbência das partes

${ }^{33}$ CHIOVENDA, Guiseppe. Principii di Diritto Processuale Civile: le azioni, il processo di cognizione. $3^{\underline{a}}$ ed. Napoli: N. Jovene, 1923, 400-401.

${ }^{34}$ LIEBMAN, Enrico Tullio. Manuale di Diritto Processuale Civile, Volume II. Milano: Giuffrè, 1959, p. 219-220.

${ }^{35}$ Cf. LIEBMAN, Enrico Tullio. Manuale di Diritto Processuale Civile, Volume II. Milano: Giuffrè, 1959.

${ }^{36}$ Cf. MORTARA, Lodovico. Manuale della Procedura Civile, Volume 1. 5a ed. Torino: Unione Tipografico-Editrice, 1906. 
na sentença. Essa audiência no tribunal a que se refere tem por característica a discussão oral do mérito da causa, sendo coordenada pelo Presidente, que tem a função de designar um relator ao processo. ${ }^{37} \mathrm{E}$ para demonstrar que essa oralidade da primeira instância não é a mesma que caracterizaria o julgamento colegiado, o autor lembra que no órgão singular também há a audiência, as partes se comunicam com o juiz, comunicam-se entre si, mas a oralidade está relacionada tanto aos esclarecimentos possíveis de serem feitos ao juiz da causa quanto à busca de um consenso ou flexibilização dos pedidos que proporcionem um acordo. A oralidade que fundamenta a colegialidade é aquela que envolve uma discussão do mérito da causa quer seja pela comunicação feita do advogado ao juiz por meio da sustentação oral ou da discussão, ou pela manifestação de posicionamentos entre os próprios juízes que compõem o colegiado. ${ }^{38}$

Neste sentido, todos os elementos discutidos pelos autores italianos consultados apontam numa concordância com os autores brasileiros no que se refere à colegialidade ser decorrente do sistema de recursos. No entanto, a fundamentação atribuída à colegialidade pelos autores italianos é diversa, em nada se relacionando com o erro de julgamento, cometimento de injustiças, fim político etc., e sim com categoria fundamental ao sistema recursal italiano: a oralidade. Nos livros acessados, não aparece uma construção deste fundamento pela doutrina italiana tal qual ocorreu na doutrina brasileira em relação à ideia do julgamento colegiado, parecendo ser algo já consolidado ao ser comentado por quase todos os autores acessados.

A oralidade é importante também para chamar a atenção do colegiado para questões de fato ou quando há a percepção de que o relator exerce influência sobre esse mesmo colegiado, agindo como um equilíbrio de forças, conforme Mortara, sendo possível inferir que a oralidade manifestada na sustentação oral do advogado perante o colegiado como uma tentativa de convencimento aos membros do colegiado. ${ }^{39}$ Independentemente das discussões que surjam a partir da oralidade, conforme será visto nos tópicos seguintes, ela se apresenta para a doutrina italiana como fundamento da colegialidade, sendo esta ideia discutida por vários autores. Chiovenda, por exemplo, se refere à ideia

${ }^{77}$ MORTARA, Lodovico. Manuale della Procedura Civile, Volume 1. $5^{\mathrm{a}}$ ed. Torino: Unione Tipografico-Editrice, 1906, p. 295-296.

${ }^{38}$ MORTARA, Lodovico. Manuale della Procedura Civile, Volume 1. $5^{\mathrm{a}}$ ed. Torino: Unione Tipografico-Editrice, 1906, p. 294-295.

${ }^{39}$ MORTARA, Lodovico. Manuale della Procedura Civile, Volume 1. $5^{\mathrm{a}}$ ed. Torino: Unione Tipografico-Editrice, 1906, p. 296-297. 
como "princípio da colegialidade". ${ }^{40}$ Além dessa, diversas outras questões são discutidas por Chiovenda, sendo a primeira delas o destaque ao processo escrito. ${ }^{41}$ Para o autor, a oralidade não deve ter a sua importância reduzida devido o código processual ser escrito, podendo tal fato ser associado até mesmo a um tradicionalismo influenciado pelo processo austríaco no sistema jurídico italiano. O destaque dado por Chiovenda representa uma separação entre as regras que regem e conduzem o direito processual das que permitem e estimulam a discussão oral do mérito da causa, podendo ir além da discussão oral ao ser considerado um princípio. ${ }^{42} \mathrm{O}$ princípio da oralidade, para Chiovenda, representa não resumi-lo apenas à audiência, mas permitir que as partes também conduzam e impulsionem o processo, tornando-o mais dinâmico. ${ }^{43}$

Mais adiante, Chiovenda afirma que o princípio da oralidade está diretamente associado à colegialidade, por estar relacionado à identidade física do juiz e à concentração do processo. ${ }^{44}$ Isso porque, tanto a identidade física do juiz quanto a concentração do processo dizem respeito aos poderes do juiz e a colegialidade flexibilizaria tal poder ao desconcentrá-lo e redistribuí-lo aos membros do colegiado, que formam um só órgão. A concentração do processo passaria a ser, então, do órgão colegiado e a identidade física do juiz persistiria ao ser proporcionado pela dinâmica que a oralidade sugere por meio da manifestação direta ao mérito da causa de todos os envolvidos no processo. Esse caráter mais dinâmico que a oralidade impõe à condução do processo, transformou-se em regra no sistema jurídico italiano, associado por Cappelletti inclusive ao brocardo jurídico "o que não está nos autos não está no mundo". ${ }^{45}$

Para Cappelletti, o brocardo latino mencionado acima representa um

${ }^{40}$ CHIOVENDA, Guiseppe. Principii di Diritto Processuale Civile: le azioni, il processo di cognizione. $3^{\mathrm{a}}$ ed. Napoli: N. Jovene, 1923, 680-681.

${ }^{41}$ Cf. CHIOVENDA, Guiseppe. Principii di Diritto Processuale Civile: le azioni, il processo di cognizione. $3^{\mathrm{a}}$ ed. Napoli: $\mathrm{N}$. Jovene, 1923.

${ }^{42}$ Cf. CHIOVENDA, Guiseppe. Principii di Diritto Processuale Civile: le azioni, il processo di cognizione. $3^{\underline{a}}$ ed. Napoli: N. Jovene, 1923.

${ }^{43}$ Cf. CHIOVENDA, Guiseppe. Principii di Diritto Processuale Civile: le azioni, il processo di cognizione. $3^{\underline{a}}$ ed. Napoli: N. Jovene, 1923.

${ }^{44}$ Cf. CHIOVENDA, Guiseppe. Principii di Diritto Processuale Civile: le azioni, il processo di cognizione. $3^{\mathrm{a}}$ ed. Napoli: N. Jovene, 1923.

${ }^{45}$ CAPPELLETTI, Mauro. Processo e Ideologie. $2^{\underline{a}}$ ed. Bologna: Il Mulino Editrice, 1969, p. 99-100. 
formalismo que não se refere tão somente ao processo escrito. ${ }^{46}$ Segundo Cappelletti, preserva também a oralidade, uma vez que a discussão oral do mérito da causa é registrada em ata, não perdendo o seu caráter escrito. ${ }^{47}$ Isto é, a regra vigente no sistema jurídico italiano para preservar e conduzir o julgamento colegiado é a oralidade, que preserva algumas exceções. Por exemplo, os registros da discussão feitos em ata referem-se aos esclarecimentos prestados ao juiz e às manifestações das partes, nunca registrando-se o falado pelos juízes que compõem o colegiado. A regra da oralidade, então, sugere mudanças sensíveis no processo civil italiano. Segundo Cappelletti, a primeira consequência é o respeito às formulações/proposições feitas na demanda judicial, considerando que as partes possuem um momento específico para mencioná-las, esclarecendo e defendendo pontos pouco destacados na petição, além de ilustrá-los com a oratória que lhes cabem..$^{48} \mathrm{E}$ a outra consequência seria o da sofisticação da argumentação jurídica, inovando em técnicas de interpretação das normas, na análise de documentos, principalmente a partir do debate oral, que sugere a necessidade de superação do argumento alheio. ${ }^{49}$

Esse dinamismo gerado ao processo civil italiano nos revela a existência de características próprias ao seu sistema jurídico. Como exemplo, é possível citar o fato de o direito brasileiro reivindicar uma proximidade com o direito processual civil italiano, importando a sua ideia do julgamento colegiado, mas deixando de importar características básicas que lhes define, como a oralidade, por exemplo. E a própria oralidade é mencionada pela doutrina a partir de diferentes manifestações, representando todas elas uma enorme discussão da demanda levada ao juízo. E, por decorrência prática, a oralidade possui outros dois desdobramentos no colegiado: a discussão e a deliberação, cada um deles merecendo tópico específico que a partir de agora passo a abordar.

${ }^{46}$ Cf. CAPPELLETTI, Mauro. Processo e Ideologie. 2aa ed. Bologna: Il Mulino Editrice, 1969.

${ }^{47}$ Cf. CAPPELLETTI, Mauro. Processo e Ideologie. $2^{\underline{a}}$ ed. Bologna: Il Mulino Editrice, 1969.

${ }^{48}$ Cf. CAPPELLETTI, Mauro. Processo e Ideologie. 2aㅡ ed. Bologna: Il Mulino Editrice, 1969.

${ }^{49}$ CAPPELLETTI, Mauro. Processo e Ideologie. $2^{a}$ ed. Bologna: Il Mulino Editrice, 1969, p. 101-102. 


\section{O MOMENTO "PORTAS ABERTAS" DO JULGAMENTO COLEGIADO: A DISCUSSÃO ORAL DO MÉRITO DA CAUSA}

No processo civil existem diversos momentos de tratamento às demandas que buscam uma prestação jurisdicional do Estado, e cada um destes momentos são responsáveis por organizar, administrar e conduzir o processo até a possível apreciação do pleito que lhe deu origem pelo órgão responsável, independentemente do sistema jurídico vigente. As formalidades que estão dispostas nos códigos escritos e que conduzem o processo são responsáveis também por estabelecer uma divisão de trabalho que permite destinar diversas fases à apreciação do processo, como: distribuição, saneamento, audiência, dentre várias outras. O julgamento colegiado compõe uma das possíveis fases ao qual o processo pode alcançar, sendo também dividido em procedimentos bem específicos e característicos da colegialidade: a discussão e a deliberação, que será mais bem abordada em tópico próprio.

E um destes procedimentos possui características bastante específicas, capaz de diferenciá-la de todas as outras fases do processo: a discussão oral do processo. Assim como nas audiências em primeira instância, o momento sugere um contato presencial entre partes, advogados e juízes. No entanto, as audiências na primeira instância não possuem por característica a discussão do mérito da causa, elas objetivam o acordo, oitiva de testemunhas e, sobretudo, o saneamento do processo. Além disso, a decisão judicial raramente é produzida neste espaço ${ }^{50}$. $\mathrm{O}$ espaço destinado às interações entre os atores envolvidos no processo que alcança o julgamento colegiado sugere uma dinâmica diferente a partir da oralidade que lhe é característica: há um número maior de juízes, há a presença obrigatória de membro do Ministério Público que inclusive compõe o colegiado, os advogados podem fazer sustentações orais, os juízes podem requerer esclarecimentos sobre questões de fato relacionadas ao processo e, além disso, há um espaço destinado à plateia.

$\mathrm{O}$ autor Enrico Redenti, ao se referir à collegialità, descreve minimamente a dinâmica ocorrida no julgamento colegiado do sistema jurídico italiano. ${ }^{51}$ Para Redenti, apesar de a oralidade conduzir o julgamento, o processo escrito não é deixado de lado a partir dos registros

${ }^{50}$ No direito brasileiro, a Lei no 9.099/1995, em seu art. 28, prevê a possibilidade de sentença ser proferida durante a audiência de instrução e julgamento nos juizados especiais.

${ }^{51}$ REDENTI, Enrico. Derecho Procesal Civil, Tomo I. Trad. Santiago Sentis Melendo e Marino Ayerra Redin. Buenos Aires: Ediciones Juridicas Europa-America, 1957, p. 459. 
que são apresentados por cada uma das partes: leitura de alegações, demonstração de provas etc. ${ }^{52}$ Ainda assim, a oralidade é característica deste momento de discussão no tribunal, podendo ainda ser visualizada em diversos momentos como o estabelecimento de um diálogo institucionalizado entre: (i) advogados e membro do Ministério Público (partes), (ii) partes e membros do colegiado, e (iii) os próprios membros do colegiado.

A oralidade das partes que estimulará a discussão é organizada a partir das manifestações a respeito do processo que integram. As chamadas sustentações orais que cada uma das partes tem direito podem tomar o caráter de reforço ao pedido da peça inicial ou contestação, combate ao argumento ou provas da parte alheia ou até mesmo de alegações finais. Ao manifestar o seu posicionamento da tribuna, cada uma das partes tem a preocupação de descaracterizar e superar o argumento da parte alheia a fim de que os membros do colegiado possam lhe conceder o pleito. Neste momento, o diálogo estabelecido entre as partes é indireto. No entanto, diferentemente do ocorrido no sistema jurídico brasileiro, as partes representadas por seus patronos, após o momento anteriormente narrado, podem diretamente discutir o mérito da causa. A contradita exercida no colegiado é regulada tanto pelo código de processo civil italiano quanto o regimento interno do tribunal, sendo responsáveis por criar um diálogo institucional entre as partes litigantes.

Por outro lado, conforme já foi iniciado acima, o diálogo estabelecido entre partes e membros do colegiado pode ocorrer das seguintes formas: sustentação oral dos advogados e membro do Ministério Público, em que realizam esclarecimentos sobre provas e tentam convencer o magistrado da legitimidade do direito que reivindicam; e esclarecimentos sobre fatos, quando requisitados por quaisquer dos membros que compõem o colegiado. Isto é, o diálogo pode ser estabelecido por iniciativa do advogado ou membro do Ministério Público, no exercício do direito de proceder à sustentação oral, ou por provocação do magistrado. Ambos os procedimentos também estão regulados pelo código de processo civil italiano e regimento interno do tribunal.

No que se refere à oralidade dos membros do colegiado, alguns pontos precisam ser destacados. $O$ primeiro deles sugere que o momento aqui narrado não é o da construção da decisão judicial, destinado ao espaço da deliberação, mas o da discussão que a antecede. O diálogo institucionalmente estabelecido entre membros de um mesmo colegiado é iniciado após as sustentações orais, hipótese em que os magistrados

52 REDENTI, Enrico. Derecho Procesal Civil, Tomo I. Trad. Santiago Sentis Melendo e Marino Ayerra Redin. Buenos Aires: Ediciones Juridicas Europa-America, 1957, p. 459. 
poderão oralmente fazer destaques ao caso analisado, pedidos de esclarecimentos, dentre outras medidas cabíveis. As manifestações orais de cada um dos magistrados presentes à sessão de julgamento são reguladas por procedimentos que permitem a realização de apartes sempre que algum dos membros do colegiado considere necessário.

A possibilidade aberta de interpelação de um magistrado a outro pode dar início a um debate sobre a matéria que lhes forem demandadas. $\mathrm{E}$ a partir da dinâmica que for impressa ao debate entre magistrados, é possível que surjam posicionamentos de cada um deles sobre a matéria discutida. Neste momento, outro destaque precisa ser dado: no único momento em que é feita uma discussão oral do mérito da causa, os juízes podem manifestar diferentes posicionamentos diante não apenas dos atores envolvidos no processo, mas de uma plateia composta por cidadãos que podem ser influenciados pela decisão que ali será construída. Diante de situações como esta, e visando diminuir possíveis pressões da opinião pública, é estabelecido um equilíbrio entre as "portas abertas" e possíveis pressões ao julgamento a partir do não registro em ata das manifestações orais de cada um dos juízes que compõem o colegiado. A medida diminui as chances de o magistrado ser constrangido a votar em determinado sentido porque o seu posicionamento pode ser falado, porém nunca escrito. O que nos remete a importantes reflexões: enquanto a oralidade das partes tem por objetivo constranger os atores envolvidos no processo, conduzindo-os a determinados convencimentos, a oralidade dos magistrados objetiva protegê-los do constrangimento.

O momento da discussão oral do processo proporcionado pela colegialidade possui uma configuração capaz de ser comparada a um espaço público de discussão privada, mas que pode afetar a todo o público que o acompanha. Isso porque, as decisões judiciais que são produtos dessas interações, podem influenciar diretamente na vida dos cidadãos dependendo do efeito e alcance que possuam. E as portas do tribunal em que ocorrem essas discussões são abertas para todos aqueles que desejam acompanhá-la de perto. Isto é, a discussão oral do mérito da causa no colegiado é o único momento do processo acompanhado de perto por qualquer cidadão que o queira. E inevitável, neste sentido, deixar de associar a colegialidade nos tribunais à visibilidade pública. No órgão colegiado, por exemplo, não existe processo sigiloso. Todos os processos são passíveis de serem analisados pelo colegiado de "portas abertas", mesmo aqueles que foram tratados de forma sigilosa antes de chegarem ao tribunal.

Em resumo, o espaço destinado à discussão oral do mérito da causa na colegialidade gera um espaço de disputas entre os atores envolvidos 
no processo, estimulados inclusive (e não apenas) pela presença de uma plateia. O que permite à criação de um espaço institucionalizado de administração de conflitos e constrangimentos, em que o mérito da causa é discutido, mas decisões não são produzidas. A construção dos votos e elaboração das decisões constituem procedimento diverso da discussão, tendo por característica um exame minucioso e secreto da causa e sendo chamado de deliberação, tema abordado no tópico a seguir.

\section{QUEM DECIDIU? A DELIBERAÇÃO SECRETA COMO GARANTIA DO MAGISTRADO}

Entendida também como uma categoria fundamental à compreensão da colegialidade, a deliberação sucede a discussão oral do mérito da causa e é caracterizada por produzir decisões judiciais. No momento destinado às interações entre partes e membros do colegiado, a oralidade imprime um dinamismo capaz de proporcionar uma discussão oral e publicizada da causa no colegiado. Diferentemente da discussão no órgão colegiado, não há como falar que a sua publicização e a oralidade caracterizam a deliberação por se tratar de um procedimento a "portas fechadas"; entretanto, tal medida não descaracteriza o colegiado. Isto é, o órgão colegiado persiste ainda que cada um de seus procedimentos e atividades não sejam completamente expostos, por continuar se tratando de uma reunião de magistrados em prol da resolução de uma controvérsia jurídica.

No sistema jurídico italiano, essa reunião de magistrados que compõem a segunda instância recursal é passível de ser assistida por quaisquer interessados apenas durante a discussão oral do mérito da causa. Além disso, é o único momento no processo em que as partes se reúnem para discuti-lo, considerando o rito diferenciado das audiências em primeira instância, em que as dinâmicas impressas às interações podem ser resumidas à proposição de acordo, oitiva de testemunhas e saneamento do processo. $\mathrm{Na}$ deliberação, os procedimentos são completamente distintos. Os juízes que compõem o colegiado podem livremente se manifestar em um eventual debate da matéria, mas eles não decidem às "portas abertas", a deliberação é secreta. A decisão, que é o fruto do debate, é tomada às "portas fechadas", o que impede que qualquer membro do colegiado tenha o seu voto exposto ao público.

O diálogo institucionalmente estabelecido ocorre tão somente entre os próprios membros do colegiado, que se reúnem na Câmara do Conselho, e na presença apenas do secretário responsável por redigir a parte 
dispositiva de decisão judicial. ${ }^{53}$ Tal procedimento impede a possibilidade de membros do colegiado proferirem decisões, sendo competência tão somente do órgão colegiado. Para Chiovenda, estas medidas protegem os membros do colegiado da pressão da opinião pública. ${ }^{54}$

Associado às questões acima, a não exposição aos procedimentos de votação também representam uma garantia ao magistrado ao preservar a sua imagem pública evitando registros a possíveis associações dos membros do colegiado a determinados posicionamentos. A impossibilidade de o magistrado declarar publicamente o seu voto, além de protegê-lo de pressões da opinião pública impede o conhecimento do público e jurisdicionado de determinados procedimentos, como: (i) o modo em que é construída uma decisão judicial colegiada; (ii) a forma em que o consenso ou maioria dos votos é alcançada; além de impedir (iii) a publicização dos votos vencidos e seus fundamentos, dentre outras questões.

E mesmo com a deliberação sendo secreta, há um rito específico à tomada de decisão do colegiado em que é atribuído destaque para algumas funções ali exercidas. Montesano e Arieta, ao descreverem tal procedimento, nos destacam algumas importantes figuras, vejamos:

La decisione, a prescindere dal tipo di provvedimento che sarà adottato (sentenza non definitiva o ordinanza), è deliberata 'in segreto nella camera di consiglio' (art. 276, primo comma). Le modalità di deliberazione presuppongono che la stessa sai sempre adottata dall'organo collegiale (l'art. 276 non è stato modificato dalla novella del 1990), ma le attività da compiersi sono le stesse anche se a decidere sai il giudice istruttore in funzione di giudice único. Sotto la direzione del Presidente il collegio decide gradatamente le questioni pregiudiziali proposte dalle parti o rilevabili d'ufficio e, sucessivamente, il merito della causa. (...) Nell'ordine delle questioni la legge si limita a disporre che quelle 'pregiudiziali' vanno decise prima del merito, ma non prevede um ordine di decisione nell'ambito delle stesse: è, peraltro, evidente che debbano, anzitutto, essere decise le questioni preliminari attinenti al processo (all'idoneità, cioè del processo a condurre ala decisione di merito) e, solo se affermativamente decise (nel senso, ad es., della sussistenza della contestata giurisdizione), a seguire altre preliminari o pregiudiziali di merito (sulla loro distinzione v. Vol. I, paragrafo 44). La decisione è presa a

${ }^{53}$ LIEBMAN, Enrico Tullio. Manuale di Diritto Processuale Civile, Volume II. Milano: Giuffrè, 1959, p. 223.

${ }^{54}$ CHIOVENDA, Guiseppe. Principii di Diritto Processuale Civile: le azioni, il processo di cognizione. $3^{a}$ ed. Napoli: N. Jovene, 1923, 403-404.

3 JOURNAL OF INSTITUTIONAL STUDIES 1 (2017) 
maggioranza di voti, ma secondo um preciso ordine di votazioni: il primo a votare è il giudice istruttore, poi l'altro giudice e, per ultimo, il Presidente. (...) Se intorno ad una questione si prospettano più soluzioni e non si forma la maggioranza alla prima votazione, il Presidente mette ai voti due delle soluzioni per escluderne una e sucessivamente pone in votazione quella non esclusa e quella eventualmente restante e così via finchè le coluzioni siano ridorre a due attorno alle quali avviene la votazione definitiva.

Chiusa la votazione il Presidente serive e sottoscrive il dispositivo, mentre la motivazione viene stesa dal relatore, salvo che il Presidente non ritenga di stenderla egli stesso o di affidarla all'altro giudice, soluzione, questa, che può rendersi necessaria o solo opportuna laddove la decisione sai stata presa a maggioranza com il voto contrario del giudice istruttore. ${ }^{55}$

De forma complementar ao trecho acima, ainda há a informação de que é possível o envio de notas (memorandos) ao colegiado para que procedam à sua leitura durante a própria deliberação. ${ }^{56}$ Todos os procedimentos destacados apontam ao menos para duas questões: a formalização de um rito e a necessidade de organização das atividades desempenhadas pelo colégio de julgadores. A primeira questão apresenta uma ordem de análise do processo: primeiro são apreciadas as questões preliminares e, em seguida, o mérito da causa. As questões são discutidas e votadas a partir de perguntas direcionadas pelo Presidente do colegiado. Em havendo empate, o Presidente apresenta nova forma de votação ao colegiado, não havendo o chamado "voto de desempate" do Presidente (como ocorre no direito brasileiro).

O outro aspecto do trecho que deve ser mencionado é a organização e distribuição das atividades entre os membros do colegiado. Em não sendo possível que todos os membros do colegiado ficassem responsáveis por gerenciar todos os atos de cada um dos processos que lhes eram submetidos à apreciação, principalmente por conta do excesso de demandas, estabeleceu-se uma divisão do trabalho. À exceção do Presidente que dirige o colegiado, as sessões de julgamento (momento em que se reúnem para discutir e deliberar) e assina a parte dispositiva da decisão judicial, a atribuição de funções ficou restrita a cada um dos processos, surgindo outras duas figuras: o juiz instrutor, responsável por sanear o processo a partir de atos de impulso oficial; e o relator, que

${ }^{55}$ MONTESANO, Luigi; ARIETA, Giovanni. Diritto Processuale Civile, 2: La

Cognizione di Rito Ordinario. Torino: G. Giappichelli, 1994, p. 180-181.

${ }^{56}$ MORTARA, Lodovico. Manuale della Procedura Civile, Volume 1. $5^{\mathrm{a}}$ ed. Torino: Unione Tipografico-Editrice, 1906, p. 299. 
prepara o processo para julgamento, apresentando ao colegiado as questões a serem debatidas e decididas.

No direito brasileiro, ocorre dinâmica inversa ao sistema jurídico italiano. Desde a edição da Lei de 18 de setembro de 1828, primeira lei de abrangência nacional a regulamentar a organização de um tribunal, há disposição que permite (i) que as sessões de julgamento sejam às "portas abertas", além de (ii) serem debatidas as questões necessárias ao regular desenvolvimento do processo ou recurso por todos os envolvidos na demanda e (iii) que a questão apreciada seja resolvida à pluralidade de votos (art. 13). O primeiro dos aspectos destacados refere-se à publicidade das sessões de julgamento, garantindo que todo aquele interessado em assisti-las possa acompanhar cada um dos procedimentos ocorridos em seu seio. A ideia das "portas abertas" sugere a compreensão de que o Supremo Tribunal estaria sempre disposto a receber os cidadãos brasileiros que demonstrassem desejo em acompanhar e conhecer não apenas as suas dinâmicas, mas as discussões de temas que podem influenciar diretamente a sua vida em sociedade.

O segundo aspecto que merece observação é a discussão das questões envolvidas na demanda judicial. Apesar da garantia de discussão dos temas que afetam diretamente a vida social, há uma mitigação dessa discussão no art. 29 da mesma lei ao estabelecer que as partes representadas por seus patronos devem discutir publicamente as questões envolvidas no processo, mas os membros do colegiado devem fazê-lo de forma secreta. A dinâmica sugerida pela lei é da discussão pública pelas partes, intervenções dos membros do colegiado com vistas a buscar os esclarecimentos que julgarem necessários, reunião às portas fechadas dos membros do colegiado para discutirem livremente a questão a ser apreciada e, por último, abertura das portas para que os juízes procedam à votação. Ou seja, no direito brasileiro, não era recomendado que os membros do colegiado se posicionassem sobre o mérito da causa durante a discussão, sendo considerado um procedimento específico da deliberação.

Por último, outro aspecto que diferencia o direito brasileiro do sistema jurídico italiano, apesar da reivindicação de proximidade entre os sistemas jurídicos principalmente pela doutrina brasileira, refere-se ao procedimento de votação. Conforme mencionado, o direito processual civil italiano impede que sejam identificadas publicamente possíveis associações entre os membros do colegiado e os votos que compuseram ou não a maioria que dirimiu a causa. $\mathrm{O}$ fundamento principal é o da preservação do magistrado diante da possibilidade de ocorrência de pressões da opinião pública, capazes de influenciar o seu julgamento. No direito brasileiro, desde a lei imperial de 1828, é criado um espaço de 
constrangimento à votação dos membros do colegiado. Além da indicação de cada um dos juízes que compõem o tribunal, estabelecer que as sessões de julgamento sejam públicas, criar dispositivos que regulam e organizam o funcionamento do tribunal, inserir um representante dos interesses da União na composição do tribunal - art. $18-$, o chefe do Poder Executivo impõe que as votações sejam públicas, obrigando que cada um dos membros do colegiado se posicionem diante de todo o público sobre a questão apreciada.

Por um lado, o procedimento acima permite uma discussão apenas entre pares sobre o fundamento da decisão, podendo ela ser um pouco mais uniforme. Por outro, permite (i) o conhecimento do posicionamento de juízes sobre determinadas matérias, além de (ii) como a maioria ou unanimidade é construída, (iii) o nível argumentativo e interpretativo de cada um dos magistrados, (iv) os votos condutores de jurisprudência, dentre outras questões. Neste sentido, é mais coerente argumentar que tradicionalmente os membros do colegiado no direito brasileiro sofrem maior influência de pressões da opinião pública. Isso porque, apesar de o primeiro regimento interno do tribunal, criado em 1891, ter modificado a dinâmica das sessões de julgamento ao tornar pública também as discussões entre os membros do colegiado, manteve a votação pública à pluralidade de votos, procedimento que permanece até os dias atuais.

Enfim, a partir da compreensão das dinâmicas ocorridas no processo de deliberação do órgão colegiado, foi possível alcançar novas categorias fundamentais à compreensão da colegialidade, como o Presidente do colegiado, juiz relator e juiz instrutor, por exemplo. No tópico seguinte, será dada ênfase nessa distribuição de funções identificada no órgão colegiado como forma de melhor compreendê-lo, momento em que será feita nova aproximação entre o processo civil italiano e o direito brasileiro.

\section{ORgANizANDO A FORÇA DE TRABALHO: OS MEMBROS DO COLEGIADO E OS ÓRGÃOS JULGADORES}

Com a possibilidade de a decisão do órgão julgador de primeira instância ser revista pelo colegiado, além das prerrogativas inerentes à instância recursal (como a discussão oral do mérito, por exemplo), as partes mais bem assistidas passaram a recorrer à possibilidade de revisão da decisão judicial como forma de se aproximar ainda mais da garantia de alcance de seu pleito judicial. Além de tais questões, a experiência na litigância judicial tanto das partes quanto de seus patronos, movimentos 
de conscientização e mobilização por direitos ${ }^{57}$, a ampliação do acesso à Justiça e o monitoramento mais próximo da apreciação de demandas pela mídia, associados à proliferação de informações ao longo dos anos, são elementos que também contribuem a um aumento da recorribilidade ao Poder Judiciário para o alcance de direitos..$^{58}$

Os elementos destacados acima refletem a possibilidade cada vez mais crescente de uma inflação judicial, o que estimula à criação de uma regulação mínima capaz de organizar e administrar a tarefa de apreciar o alto número de demandas que chegam ao Poder Judiciário, dado a desproporção entre o número de demandas judiciais existentes e os juízes disponíveis e aptos a apreciá-las. Fazendo referência especificamente à segunda instância recursal, por estar mais próximo do escopo do presente estudo, é possível destacar a impossibilidade de todas as demandas que chegam ao órgão colegiado serem apreciadas em sua completude por cada um seus membros. Assim, de forma a imprimir celeridade e maximizar a capacidade produtiva do órgão julgador, foi feita uma organização do trabalho de modo a distribuir funções entre os membros do colegiado em relação a cada um dos recursos e processos originários de competência do órgão, como a criação das figuras do Presidente, Vicepresidente, Instrutor, Relator, Revisor e Vogal. As linhas a seguir não têm o propósito de esgotar cada uma das funções, mas traçar características básicas que lhes definem e distinguem um dos outros.

Os sistemas jurídicos brasileiro e italiano se assemelham no que se refere aos aspectos destacados acima, possuindo inclusive proximidades entre alguns papéis exercidos no seio do colegiado. O Presidente do órgão colegiado, por exemplo, conforme visto no tópico anterior, pode ser considerado o "guardião dos procedimentos", responsável por salvaguardar o funcionamento adequado e regular do tribunal a partir tanto dos dispositivos constantes nos códigos e regimento interno quanto das regras não escritas, fruto de tradicionalismos preservados pela manutenção de determinados hábitos pelos próprios membros do tribunal. O Presidente do tribunal é a sua principal autoridade, sendo responsável por representá-lo e lhe dar voz perante quaisquer situações em que seja demandado, além de estabelecer relações entre o órgão julgador e os demais órgãos e instituições judiciárias, administrativa ou legislativa.

${ }^{57}$ Cf. McCANN, Michael. Rights at Work: Pay Equity Reform and Politics of Legal Mobilization. Chicago, IL: The University of Chicago Press, 1994.

${ }^{58}$ Cf. CAPPELLETTI, Mauro; GARTH, Bryant. Acesso à Justiça. Trad. Ellen Gracie Northfleet. Porto Alegre, RS: Sergio Antonio Fabris Editor, 1988. 
No direito brasileiro, o Presidente do colegiado, tradicionalmente, mantém relações principalmente com o chefe do Poder Executivo. Desde a edição da Lei de 18 de setembro de 1828 , que cria e regulamenta o Supremo Tribunal de Justiça, atual Supremo Tribunal Federal (STF), é formalmente estabelecida uma relação de proximidade entre Presidente do tribunal superior e chefe do Poder Executivo. Além do chefe do Poder Executivo nomear os membros do Supremo Tribunal, nomeava também o seu Presidente, determinando o período que ocuparia o cargo e as responsabilidades ao assumi-lo. Esse procedimento durou até a autonomização do tribunal para criar suas próprias regras procedimentais, inaugurado em 1891 com a criação do primeiro regimento interno do tribunal. Nesse regimento também foram regulamentadas as funções do vice-presidente do tribunal, cuja função precípua era substituir o presidente em seus impedimentos temporários e, estando o vice-presidente ausente, assumiria as suas funções o juiz mais idoso do tribunal (arts. 17 - 19). A substituição ao vice-presidente foi alterada logo no regimento interno posterior, datado de 1909, quando o ministro mais antigo do tribunal passou a substituí-lo, o que prevalece até os dias atuais.

Considerando o Presidente do colegiado como o guardião dos procedimentos no tribunal, alguma figura teria que ser criada para imprimir a mesma lógica procedimental em cada um dos processos apreciados pelo órgão julgador, considerando a incapacidade gerencial do Presidente para fazê-lo devido a já mencionada inflação judicial. E a partir da competência destinada ao Presidente por gerenciar a distribuição dos processos entre os membros do colegiado, criou-se no sistema jurídico italiano a figura do juiz instrutor, responsável por constituir as provas necessárias à instrução do processo, como inquirição de testemunhas, análise de provas documentais e pericial, convocar audiências de instrução e saneamento do processo, dentre outras medidas. ${ }^{59} \mathrm{O}$ objetivo era auxiliar o membro do colegiado que recebesse o recurso ou processo distribuído, diminuindo algumas de suas funções ao liberá-los dos atos de impulso oficial e administrativo (destinados ao juiz instrutor), atribuindo-lhes a competência precípua de analisar o mérito da causa.

Diferentemente do sistema jurídico italiano, no direito brasileiro, a figura do juiz instrutor foi criada apenas em 2009, com a edição da Lei no $12.019 / 2009$, que permite a criação do cargo em cada um dos gabinetes dos ministros do STF. O objetivo é que o juiz instrutor proceda à coleta

${ }^{59}$ Cf. MONTESANO, Luigi; ARIETA, Giovanni. Diritto Processuale Civile, 2: La Cognizione di Rito Ordinario. Torino: G. Giappichelli, 1994. 
de provas nos processos penais de competência originária do tribunal e forneça ao ministro as informaç̃es que contribuam à análise do mérito da causa, imprimindo maior celeridade nos julgamentos. Esse juiz ou ministro que recebe as informações do juiz instrutor para proceder aos julgamentos dos recursos ou processos que lhes são distribuídos recebem a denominação de relator. $\mathrm{O}$ juiz relator é responsável, dentre outras medidas, por fazer um resumo de todo o litígio para apresentar aos demais colegas do colegiado, durante a sessão de julgamento, e elaborar voto sobre o mérito da causa. Segundo Mario Casarino Viterbo, ao escrever sobre o sistema processual italiano e as funções dos membros do colegiado, destaca que uma das principais funções do Relator é destacar o assunto ou conteúdo do processo a ser apreciado pelo tribunal. ${ }^{60}$

A fixação do assunto ou conteúdo do processo representa também pautar os principais tópicos de discussão da causa pelo tribunal, permitindo que o juiz relator atribua um tom próprio à causa. Somadas às funções acima, Viterbo destaca também que está entre as funções do Relator, fazer um relatório do recurso ou processo e apresentar ao tribunal, elaborar a ementa de decisão, gerenciar os recursos ou processos que estão sob sua responsabilidade, acompanhar e regular o prazo dos prováveis pedidos de vista. ${ }^{61}$ No órgão colegiado italiano, atribuído os destaques às figuras do presidente, instrutor e relator, todos os outros membros do colegiado possuem a função de ouvir ou ler o relatório do recurso ou processo, discutir oralmente o mérito da causa e proceder ao seu respectivo voto.

Diferentemente do sistema jurídico italiano, no direito brasileiro o relator possui atribuições bastante destacadas no colegiado, permitindo inclusive uma mudança de características das sessões de julgamento, o que será abordado de forma mais detalhada no tópico seguinte. Para a compreensão deste tópico e do argumento que vem sendo construído ao longo de todo o texto, é importante destacar traços distintivos das funções atribuídas àqueles que visivelmente compõem o colegiado, de modo a identificar uma distribuição de competências responsáveis por gerenciar o funcionamento do órgão colegiado. Assim, destacam-se outras figuras no órgão colegiado brasileiro, como o revisor, o vogal, o procurador-geral da República (no Supremo Tribunal Federal) e o secretário do plenário.

Após o relator exercer o seu papel principal de elaborar um relatório fixando todas as questões que merecem apreciação do colegiado, o direito

${ }^{60}$ VITERBO, Mario Casarino. Manual de Derecho Procesal: Derecho Procesal

Orgánico, Tomo II. $2^{a}$ ed. Santiago: Editorial Jurídica de Chile, 1970, p. 149-150.

${ }^{61}$ VITERBO, Mario Casarino. Manual de Derecho Procesal: Derecho Procesal

Orgánico, Tomo II. $2^{a}$ ed. Santiago: Editorial Jurídica de Chile, 1970, p. 151-153. 
brasileiro criou a figura do juiz revisor, que é aquele responsável (i) por dar um visto caso concorde com as considerações feitas pelo relator ou (ii) fazer novo relatório caso apresente uma discordância sobre os pontos por ele fixados. O autor Alcides de Mendonça Lima, que escreveu um livro sobre as modificações geradas pelo Código de Processo Civil de 1973 no sistema recursal brasileiro, destaca a necessidade de o revisor apreciar o relatório feito pelo Relator e reexaminar os autos, dentre outras questões. ${ }^{62}$

A figura do revisor possui reminiscência histórica, aparecendo pela primeira vez no Regimento Interno do Supremo Tribunal Federal de 1891, em seu artigo 43, exercendo funções complementares a do relator ao revisar o seu relatório e permanecendo ainda nos dias atuais, sendo regulado a partir do art. 23 do Regimento Interno atual do STF. Ao lado dos juízes relator e revisor, estão os juízes vogais. Segundo leitura dos Regimentos Internos do STF de 1970 e 1980 (atual), nos arts. 339 e 358, respectivamente, o vogal é aquele que não foi o relator nem o revisor da demanda apreciada pelo colegiado, mas que profere voto a partir do que foi pautado na sessão de julgamento. Ou seja, o juiz ou ministro vogal é todo aquele que profere voto sem ter tido acesso aos autos do processo ou recurso analisado pelo tribunal, tendo por base apenas o relatório elaborado pelo juiz ou ministro relator e a discussão ocorrida no próprio colegiado. Ao juiz vogal cumpre a função de participar do julgamento das demandas apreciadas pelo colegiado e proferir voto.

Além das funções acima destacadas e distribuídas entre os membros do colegiado, há duas figuras que o compõem e não possuem poder de voto por não serem de juízes: o Procurador-Geral da República e o secretário do plenário. O Procurador-Geral da República, chefe do Ministério Público nacional, assume um lugar perante o colegiado desde a edição do primeiro Regimento Interno do STF, datado de 1891, quando assume o papel de verificar e acompanhar a aplicação de leis, regulamentos e decretos, além de representar os interesses do Ministério Público nos casos em que lhe for demandado. Além de compor o colegiado, o Procurador-Geral da República tem a competência de propor demandas judiciais perante o próprio colegiado, atuando como parte. $\mathrm{O}$ Procurador-Geral é indicado pelo Presidente da República, sendo submetido à aprovação do Senado Federal, e possui assento no colegiado ao lado direito do Presidente do Tribunal.

Por fim, o último integrante do órgão colegiado é o secretário do plenário. A previsão do cargo existe desde a Lei de 18 de setembro de

${ }^{62}$ LIMA, Alcides de Mendonça. Introdução aos Recursos Cíveis. $2^{a}$ ed. São Paulo, SP: Revista dos Tribunais, 1976, p. 375-376.

3 JOURNAL OF INSTITUTIONAL STUDIES 1 (2017) 
1828, que permite que o Presidente do Tribunal indique um secretário que lhe auxilie no cumprimento dos protocolos no colegiado (art. $5^{\circ}$ ), além de fazer registros acerca das dinâmicas ali ocorridas. $\mathrm{O}$ cargo foi regulamentado no primeiro Regimento Interno do STF e continua a existir até os dias atuais. Explicitados cada uma das funções exercidas pelos membros do colegiado, é importante destacar ainda que brevemente outra forma de organização e administração da força de trabalho no colegiado: a sua divisão em câmaras ou turmas.

A divisão do tribunal em câmaras ou turmas já existia enquanto movimento desde a metade do século XVIII, quando foi criado o tribunal de Relação do Rio de Janeiro, que dividia o tribunal em quatro câmaras compostas por dois juízes cada, reunindo todos os seus membros no plenário do tribunal. Argumenta-se que tanto a criação do tribunal da Relação do Rio de Janeiro quanto a sua divisão em câmaras objetivava diminuir a quantidade de processos destinada ao Tribunal da Relação da Bahia, redistribuindo as demandas judiciais devido a inflação judicial que já se verificava à época. ${ }^{63}$ Com o seguimento da mesma organização pelos tribunais posteriores, convencionou-se dividi-los em câmaras ou turmas para fins de uma melhor organização judiciária e distribuição da força de trabalho entre seus membros.

No entanto, o movimento acima chega aos tribunais superiores dois séculos depois, após a criação e atuação do Supremo Tribunal de Justiça que, posteriormente passou a ser chamado de Supremo Tribunal Federal, com a autorização pela Constituição Federal de 1934 à divisão do tribunal em turmas. E, em 1937, o Decreto-Lei no 6 instituiu o sistema de turmas no STF, dividindo-o em duas turmas capazes de reorganizar a competência do tribunal e redistribuir processos entre os três órgãos: primeira turma, segunda turma e plenário (reunião de todos os juízes que compõem o colegiado). Por possuir um número ímpar de ministros, o Presidente do Tribunal foi excluído da composição de alguma das turmas e, definido o número par, cada uma das metades dos ministros passou a compor uma das turmas. No plenário, o Presidente se reunia com os integrantes das duas turmas para apreciar conflitos de posicionamentos entre as turmas, além das causas que demandavam maior complexidade ou de competência originária do plenário. ${ }^{64}$ No Supremo Tribunal

${ }^{63}$ Cf. MELLO, Isabelle de Matos Pereira de. Magistrados a serviço do Rei: a administração da Justiça e os ouvidores gerais na comarca do Rio de Janeiro (17101790). Tese (Doutorado em História Social), Programa de Pós-Graduação em História Social, Universidade Federal Fluminense, Niterói, 2013.

${ }^{64}$ LIMA, Alcides de Mendonça. Introdução aos Recursos Cíveis. $2^{a}$ ed. São Paulo, SP: Revista dos Tribunais, 1976, p. 147-148. 
Federal, o Regimento Interno atual estabelece ainda que o vice-presidente do Tribunal comporá e presidirá uma das turmas, e o ministro mais antigo que ainda não houver exercido a presidência exercerá a da outra turma. Além disso, os Subprocuradores-Gerais da República comporão cada uma das turmas como representantes do Ministério Público (art. 48).

Os procedimentos aqui mencionados podem ser resumidos como uma divisão da força de trabalho entre os membros do tribunal ao distribuir cargos e funções a cada um deles, além dos processos e recursos entre os três órgãos julgadores que compõem o colegiado. Essa procedimentalização que se convencionou adotar em prol de supostas melhorias no funcionamento do colegiado demonstram algo além: cada um dos membros do colegiado são juízes, mas singularmente considerados e no exercício de cada uma das funções que lhes cabem, não são considerados órgãos julgadores. Essa categoria é destinada pela doutrina para caracterizar aqueles que possuem a competência para decidir o mérito da causa, podendo ser notado a partir da relação entre membros do colegiado singularmente considerados, órgãos julgadores e mérito da causa.

Apesar de exposto no presente tópico, é importante destacar que a divisão de competências e distribuição de funções, seja entre membros do colegiado ou câmaras e turmas, se modifica ao longo do tempo, sendo capazes de alterar inclusive características básicas e definidoras da colegialidade. $\mathrm{O}$ tópico seguinte, por exemplo, demonstrará que, mesmo a doutrina brasileira passando décadas sem aprofundar o tema da colegialidade, o fenômeno da ampliação dos poderes do relator no tribunal pode alterar profundamente as características do órgão colegiado. Esse movimento de ampliação dos poderes do relator permitirá que, após décadas, a colegialidade seja novamente discutida no direito brasileiro a partir de vários elementos anteriormente esquecidos pela doutrina clássica do direito processual civil brasileiro, como a oralidade, sendo inclusive reivindicada como um tema constitucional. De forma bem resumida, este será o assunto abordado no próximo tópico.

\section{A REIVINDICAÇÃo DOS JURISTAS À Constitucionalização do Processo Civil}

No direito brasileiro, após a doutrina clássica do direito processual civil tecer comentários a respeito da colegialidade, somente após a necessidade de reorganização e administração da força de trabalho do colegiado e seus membros o tema volta ser discutido na doutrina, ocorrendo principalmente a partir da edição de marcos legislativos. Isto 
é, a autonomização dos tribunais brasileiros com a criação de regimentos internos não foi o bastante à criação de cargos e funções dentre seus próprios membros, apenas conseguindo regulamentar algumas das funções mencionadas nas leis. Por exemplo, ao Relator são atribuídas funções que se modificam bastante ao longo dos anos, estimulando que autores brasileiros voltem a escrever sobre a colegialidade, mas sob o prisma do Relator.

Em comparação ao primeiro Código de Processo Civil brasileiro, de 1939, a edição do Código de 1973 amplia os poderes do relator, permitindo que sumariamente indefira o agravo ${ }^{65}$, manifestamente improcedente, que são aqueles em manifesto confronto com súmulas ${ }^{66}$, ou jurisprudência ${ }^{67}$ dominante, exigindo uma apreciação de caráter subjetivo do julgador, considerando ser necessário demonstrar a similaridade entre (i) os julgados que servem de parâmetros à sua decisão e (ii) a questão recorrida. Apesar da atribuição de mais poderes ao relator, a doutrina brasileira não discutiu profundamente a referida questão, dando destaque ainda à competência que o relator possui para elaborar o relatório no processo. Segundo Mendonça Lima, a criação do relatório é a principal competência do relator, principalmente por pautar os pontos a serem discutidos no processo. ${ }^{68}$

Uma das questões passíveis de reflexão destacadas por Lima é a da distribuição de funções entre os membros do colegiado com o objetivo de imprimir maior celeridade no cumprimento das tarefas incumbidas ao tribunal e cumpridas por seus membros. ${ }^{69}$ Percebe-se que a necessidade de uma descentralização da força de trabalho, na visão daqueles que atuam direta ou indiretamente perante o tribunal, pode contribuir ao melhor exercício das funções atribuídas aos seus membros, além da apreciação de um número maior de demandas a partir da celeridade impressa às dinâmicas do tribunal. A celeridade na apreciação de

${ }^{65}$ Agravo é o recurso destinado à recorribilidade das decisões interlocutórias no bojo do processo, ou seja, àquelas que não apreciam o mérito da demanda (Ver artigo $522 \mathrm{e}$ seguintes do Código de Processo Civil brasileiro).

${ }^{66}$ São pequenos textos, considerados enunciados normativos, fixados pelo próprio tribunal para consolidar entendimento sobre matéria já apreciada no colegiado.

${ }^{67}$ A jurisprudência representa o posicionamento do tribunal a respeito de matéria já discutida no colegiado, mas que ainda não foi editada em um texto capaz de criar um enunciado normativo que sirva de orientação ao tribunal como se norma fosse.

${ }^{68}$ LIMA, Alcides de Mendonça. Introdução aos Recursos Cíveis. 2ª ed. São Paulo, SP: Revista dos Tribunais, 1976, p. 374.

${ }^{69}$ LIMA, Alcides de Mendonça. Introdução aos Recursos Cíveis. 2ª ed. São Paulo, SP: Revista dos Tribunais, 1976, p. 374. 
demandas pelo Poder Judiciário aponta como principal fonte de preocupação daqueles que possuem uma relação de proximidade com as instituições judiciárias, o que ocorre desde a organização do próprio sistema jurídico, conforme demonstrado inclusive no tópico anterior.

Outra reflexão a merecer destaque, inclusive em relação ao papel cumprido pelo relator, é a característica que possui de pautador da discussão. Por ter a competência de elaborar uma exposição pormenorizada dos fatos e das questões a serem discutidas, o relator invariavelmente pauta a discussão que deve ser levada adiante pelos membros do colegiado, apontando principalmente as questões relevantes ou não ao debate. Tal medida pode tanto diminuir o trabalho dos demais membros do colegiado, ao evitar que todos leiam cada uma das demandas judiciais por inteiro, quanto influenciar na tomada de decisão devido o direcionamento feito pelo relator das questões a serem apreciadas pelo colegiado. Este último fenômeno pode ocorrer a partir da interpretação do magistrado, das suas convicções pessoais, de experiências vividas etc., por diversos elementos que o permitam ter uma compreensão do caso que está apreciando.

Apesar da mudança do papel exercido pelo relator no Código de Processo Civil de 1973, ampliando os seus poderes, a doutrina processual brasileira parece não ter atribuído destaque em tal medida a partir da ausência de textos que abordassem a matéria. $O$ tema da ampliação de poderes do relator e, consequentemente, da colegialidade, voltam a ser discutidos pouco mais de vinte anos depois, novamente com a edição de leis que modificam novamente as competências do relator, perante o seu órgão de atuação, que é o colegiado. A Lei nº 9.139/1995 modifica novamente os poderes do relator de modo a permitir que negue seguimento a recurso manifestamente inadmissível, prejudicado, improcedente ou contrário à súmula do respectivo tribunal ou de tribunal superior.

O recurso inadmissível refere-se a um juízo de forma, em que reside o exame de admissibilidade do recurso, verificando o atendimento de elementos como: cabimento e adequação do recurso, interesse e legitimidade do recorrente, inexistência de fatos que impeçam o recurso de ser interposto, pagamento de custas, tempestividade e regularidade formal. O não atendimento a quaisquer destes elementos pode tornar o recurso inadmissível. Diferentemente, no recurso manifestamente prejudicado é feita a análise prévia acerca da potencial perda do objeto do recurso. As razões da caracterização do recurso como manifestamente prejudicado são assentadas em fatos incontroversos, que resultam na 
desnecessidade de seu seguimento..$^{70}$ Essas medidas são verificadas assim que o recurso é distribuído ao seu relator, permitindo que impeça cada vez mais que recursos sejam apreciados pelo órgão colegiado a partir dos novos poderes que possui.

Em seguida, cerca de três anos mais tarde, é editada a Lei nº 9.756/1998 que amplia ainda mais os poderes do relator para, além dos já mencionados, dar provimento ao recurso se a decisão recorrida estiver em manifesto confronto com súmula ou com jurisprudência dominante de tribunal superior ou do STF (no caso de seus próprios ministrosrelatores). A inovação desta medida legislativa é conceder ao relator a competência de apreciar o mérito da demanda para dar provimento recurso, impedindo que mais recursos possam chegar à apreciação do colegiado. Esse movimento de ampliação da competência do relator gerou reação em autores mais recentes do processo civil brasileiro ao discutirem a legalidade e constitucionalidade de tais medidas a partir principalmente de possíveis consequências à sua implementação.

Todas as modificações legislativas acima geraram reações entre os juristas, contribuindo ao estabelecimento de um debate acerca da possibilidade de tais medidas suprimirem instâncias ou etapas próprias ao sistema jurídico brasileiro, conforme brevemente destacado por José Carlos Barbosa Moreira ${ }^{71}$ - um dos primeiros e mais citados autores dentre os que escreveram sobre o tema. $\mathrm{O}$ autor reconhece, no trecho acima, a existência de uma tradição no sistema jurídico brasileiro em que o órgão colegiado é a instância de apreciação dos recursos ao argumentar que tal competência está sendo transferida aos relatores. O possível efeito argumentado pelo autor é o de uma inversão à lógica de funcionamento do colegiado, passando os tribunais brasileiros a adotarem o monocratismo como regra e o colegiado como uma exceção à apreciação das demandas que alcançam a segunda instância ou instâncias superiores. Conforme mencionado anteriormente, categorias como oralidade, discussão e deliberação não foram importadas pelo direito brasileiro como meio de fundamentar e compreender a colegialidade. Algumas dessas categorias surgem a partir do fenômeno evidenciado no tópico anterior: a organização da força de trabalho e distribuição das funções entre os membros do órgão colegiado.

${ }_{70}$ ALVIM, José Eduardo Carreira. Novo Agravo. $4^{\mathrm{a}}$ ed. Rio de Janeiro, RJ: Forense, 2002, p. 122.

${ }^{71}$ MOREIRA, José Carlos Barbosa. Algumas inovações da Lei 9.756 em matéria de Recursos Cíveis. In: Tereza Arruda Alvim Wambier; Nelson Nery Jr. (Orgs.). Aspectos polêmicos e atuais dos Recursos Cíveis de acordo com a Lei 9.756/98. São Paulo, SP: Revista dos Tribunais, 1999, p. 324. 
Além de tais questões, Cândido Rangel Dinamarco destaca outra ao afirmar que, apesar de o direito brasileiro reivindicar uma proximidade com o sistema jurídico italiano, caminha em direção oposta, destacando que reforma recente no direito processual italiano optou por diminuir os poderes do relator a fim de proteger a regra da colegialidade. ${ }^{72}$

A partir das questões destacadas, os autores mais recentes do processo civil brasileiro, apesar dos diferentes caminhos percorridos, são unívocos no discurso proferido para se manifestarem contrário à ampliação aos poderes do relator, dando início a um novo movimento: a constitucionalização do processo civil brasileiro. Esse movimento pode ocorrer por diferentes caminhos: (i) a extração de categorias constantes nos textos constitucionais e o estabelecimento de uma relação com a questão enfrentada; e (ii) a elevação de uma categoria própria ao processo civil ao status constitucional por meio do empenho de um trabalho intelectual específico (argumentação e/ou interpretação, por exemplo). Os dois caminhos percorridos pelos autores que reivindicam essa constitucionalização do processo civil podem ser notados a partir da (re)construção do debate acerca da ampliação de poderes do relator e a suposta supressão de instâncias no ordenamento jurídico brasileiro.

A partir das ponderações acima, o próprio Dinamarco atribui status constitucional à colegialidade ao defender que a sua supressão pela ampliação dos poderes do relator violaria o que chama de "garantia do juiz natural", considerando se tratar da colegialidade como o juiz natural dos recursos. ${ }^{73}$ Inaugurado o debate acerca da suposta supressão da colegialidade pelos aumentos aos poderes do relator, os autores de direito processual civil uniformizam um discurso acerca da já mencionada constitucionalização do processo civil, utilizando-se dos mais diversos caminhos. Por exemplo, autores como Barbosa Moreira e Didier Jr. e Cunha entendem que a ampliação de poderes do relator impede a apreciação de recursos pelo colegiado, ocasionando suposta violação ao duplo grau de jurisdição. ${ }^{74}$ Segundo os autores, o duplo grau de

72 DINAMARCO, Cândido Rangel. O relator, a jurisprudência e os recursos. In: Tereza Arruda Alvim Wambier; Nelson Nery Jr. (Orgs.). Aspectos polêmicos e atuais dos Recursos Cíveis de acordo com a Lei 9.756/98. São Paulo, SP: Revista dos Tribunais, 1999, p. 130.

${ }^{73}$ DINAMARCO, Cândido Rangel. O relator, a jurisprudência e os recursos. In: Tereza Arruda Alvim Wambier; Nelson Nery Jr. (Orgs.). Aspectos polêmicos e atuais dos Recursos Cíveis de acordo com a Lei 9.756/98. São Paulo, SP: Revista dos Tribunais, 1999, p. 132.

${ }^{74}$ Cf. MOREIRA, José Carlos Barbosa. Comentários ao Código de Processo Civil, Volume V. $8^{\mathrm{a}}$ ed. Rio de Janeiro, RJ: Forense, 2000; e DIDIER JR., Fredie; CUNHA, 
jurisdição é um princípio constitucional decorrente da organização judiciária, ao qual está sendo violado ao impedir que uma demanda oriunda de um juiz singular seja revista pelo órgão colegiado competente. ${ }^{75}$

Indo ao encontro do discurso mencionado anteriormente, Leonardo Greco sustenta que em casos de decisão monocrática do recurso de apelação, a garantia da sustentação oral do apelante é violada, uma vez que o recurso de apelação é caracterizado pela oralidade. A ausência de sustentação nesta hipótese representaria, na visão do autor, uma mitigação ao contraditório, ao qual considera uma garantia constitucional que está sendo violada. ${ }^{76}$

Além da suposta violação argumentada pelo autor no trecho acima, é possível identificar uma preocupação com a oralidade no sistema recursal, categoria que não foi importada pelo direito brasileiro como fundamento da colegialidade, mas que passa a ser reivindicada por meio inclusive da sua atribuição a um status de constitucionalidade, como sendo componente do exercício ao contraditório. O mesmo autor argumenta ainda que a colocação em mesa dos recursos para julgamento viola o que chama de "garantia da publicidade", devido a não colocação do recurso em pauta para julgamento. ${ }^{77}$ Tais questões inserem novamente a categoria da colegialidade no centro dos debates de direito processual civil, agora, também por meio da argumentação e interpretação constitucional.

As modificações legislativas acima, ao ampliar os poderes do relator, influenciam diretamente na dinâmica de trabalho dos órgãos colegiados. Sidnei Beneti, ministro aposentado do Superior Tribunal de Justiça, argumenta, por exemplo, a ocorrência de dois eventos: um micro, ao se referir às mudanças nos aspectos práticos do trabalho no colegiado; e outro macro, no sentido de haver uma lógica invertida no direito

Leonardo José Carneiro da. Curso de Direito Processual Civil, Vol. 3: Meios de Impugnação às Decisões Judiciais e Processos nos Tribunais. $5^{\mathfrak{a}}$ ed. Salvador, BA: JusPODIVM, 2008.

${ }^{75}$ Cf. MOREIRA, José Carlos Barbosa. Comentários ao Código de Processo Civil, Volume V. 8aㅡ ed. Rio de Janeiro, RJ: Forense, 2000, p. 238; e DIDIER JR., Fredie; CUNHA, Leonardo José Carneiro da. Curso de Direito Processual Civil, Vol. 3: Meios de Impugnação às Decisões Judiciais e Processos nos Tribunais. $5^{\underline{a}}$ ed. Salvador, BA: JusPODIVM, 2008, p. 27-28.

${ }^{76}$ GRECO, Leonardo. Estudos de Direito Processual. Campos dos Goytacazes, RJ: Ed. Faculdade de Direito, 2005, p. 305-306.

${ }_{77}$ GRECO, Leonardo. Estudos de Direito Processual. Campos dos Goytacazes, RJ: Ed. Faculdade de Direito, 2005, p. 310. 
brasileiro ao privilegiar o monocratismo em detrimento da colegialidade. ${ }^{78}$ Esse monocratismo aparente parece ter se tornado regra nos julgamentos colegiados brasileiros, na visão dos autores aqui citados, fenômeno acentuado também a partir da maior visibilidade de julgamentos colegiados que a TV Justiça proporciona ao transmitir ao vivo as sessões de julgamento do Supremo Tribunal Federal. Esse último entendimento é importante para destacar outra abordagem que tem sido atribuída à colegialidade, mas sob o enfoque da deliberação: a tentativa de identificação de uma racionalidade ou simples compreensão da dinâmica decisória dos membros do colegiado.

Essa abordagem se aproxima aos estudos recentes que produzem análises do processo decisório no Brasil, representando outro esforço intelectual que também insere a categoria da colegialidade em evidência no debate jurídico. A categoria fundamental de compreensão da colegialidade neste debate se resume ao procedimento da deliberação. Por seu intermédio, são realizados estudos que tem por objetivo investigar como os juízes ou ministros tomam decisões judiciais. Apesar de o debate proposto por essa linha de pesquisa ser diferente da aqui proposta, por se tratar de meio que atribui nova visibilidade à categoria da colegialidade no Brasil, a inserindo também no centro do debate jurídico, é importante compreender ainda que de forma básica os seus aspectos fundamentais, o que será visto no tópico a seguir.

\section{A MOVIMENTAÇÃO DOUTRINÁRIA PELA APROPRIAÇÃO DO DISCURSO CONSTITUCIONAL}

A análise do processo decisório no Brasil centraliza os seus estudos principalmente a partir de investigações às dinâmicas ocorridas nas deliberações do plenário de órgãos colegiados. Como a TV Justiça colocou em maior evidência os julgamentos ocorridos nas sessões plenárias do Supremo Tribunal Federal, não é incomum nos depararmos com muitas análises sobre o STF que afirmam a inexistência de uma deliberação na Corte diante dos casos julgados. ${ }^{79}$ Conrado Hübner, por exemplo,

\footnotetext{
${ }^{78}$ Cf. BENETI, Sidnei. Monocratismo, monologuismo e colegialidade nos tribunais. In: Jorge Mussi; Luiz Felipe Salomão; Napoleão Nunes Maia Filho (Org.). Estudos Jurídicos em Homenagem ao Ministro Cesar Asfor Rocha, Vol. III. Ribeirão Preto, SP: Migalhas, 2012.

${ }^{79}$ Cf. DE SETA, Cristina Gomes Campos. “Vistos, relatados e discutidos estes autos, acordam os Ministros do Supremo Tribunal Federal"... Mas, há consenso na
} 
caracteriza a existência de "onze ilhas" no STF para destacar a falta de diálogo e de deliberação entre os ministros. ${ }^{80}$

A partir também dessa aparente ausência de deliberação ou deliberação mitigada, muitos estudos têm sido desenvolvidos com o propósito de investigar "como os ministros decidem". Os estudos mais recentes sobre o tema ${ }^{81}$ investigam a existência ou não de um processo

construção das decisões do Supremo Tribunal Federal? Tese (Doutorado em Direito), Programa de Pós-Graduação em Direito, Universidade Gama Filho, 2012.

${ }^{80}$ Cf. Mendes, Conrado Hübner. Onze Ilhas. Folha de São Paulo: Tendências e

Debates, São Paulo, SP, 01 fev. 2010.

${ }^{81}$ É possível citar os estudos recentes de: ARGUELHES, Diego Werneck; RIBEIRO, Leandro Molhano. As indicações presidenciais para o Supremo Tribunal Federal e seus fins políticos: uma resposta a Mariana Prado e Cláudia Turner. Revista de Direito Administrativo - RDA, Vol. 255, 2010; RIBEIRO, Leandro Molhano; ARGUELHES, Diego Werneck. Preferências, Estratégias e Motivações: pressupostos institucionais de teorias sobre comportamento judicial e sua transposição para o caso brasileiro. Revista Direito e Práxis, Vol. 4, 2, 2013; DE SETA, Cristina Gomes Campos. “Vistos, relatados e discutidos estes autos, acordam os Ministros do Supremo Tribunal Federal"... Mas, há consenso na construção das decisões do Supremo Tribunal Federal? Tese (Doutorado em Direito), Programa de Pós-Graduação em Direito, Universidade Gama Filho, 2012; OLIVEIRA, Fabiana Luci de. O Supremo Relator: Processo Decisório e mudanças na composição do STF nos Governos FHC e Lula. Revista Brasileira de Ciências Sociais, Vol. 27, 80, 2012; OLIVEIRA, Fabiana Luci de. Processo Decisório no Supremo Tribunal Federal: Coalizões e "Panelinhas". Revista de Sociologia Política, Vol. 20, 44, 2012; OLIVEIRA, José Aparecido de; EPSTEIN, Isaac. Tempo, Ciência e Consenso: os diferentes tempos que envolvem a Pesquisa Científica, a Decisão Política e a Opinião Pública. Interface (Botucatu): Communication, Health, Education, Vol. 13, 29, 2009; TÜRNER, Claudia; PRADO, Mariana. A Democracia e o seu impacto nas nomeações dos Diretores das Agências Reguladoras e Ministros do STF. Revista de Direito Administrativo - RDA, No. 250, 2009; SILVA, Virgílio Afonso da. O STF e o Controle de Constitucionalidade: Deliberação, Diálogo e Razão Pública. Revista de Direito Administrativo - RDA, No. 250, 2009; SILVA, Virgílio Afonso da. Deciding Without Deliberating. International Journal of Constitutional Law, Vol. 11, 3, 2013; COUTINHO, Diogo R.; VOJVODIC, Adriana de Moraes (Orgs.). Jurisprudência Constitucional: Como Decide o STF? São Paulo, SP: Malheiros/SBDP, 2009; VOJVODIC, Adriana de Moraes; MACHADO, Ana Mara França; CARDOSO, Evorah Lusci Costa. Escrevendo um Romance, Primeiro Capítulo: Precedentes e Processo Decisório no STF. Revista Direito GV, Vol. 5, 1, 2009; e MENDES, Conrado Hübner. Constitutional Courts and Deliberative Democracy. Oxford: Oxford University Press, 2013. 
decisório - ou "processos decisórios", na impossibilidade de identificação de processo único na produção de decisões judiciais ${ }^{82}-$, levando-se em consideração o aumento tanto de (i) visibilidade no cenário político ${ }^{83}$ quanto da (ii) atuação e competência do $\mathrm{STF}^{84}$ por meio das decisões que os próprios ministros proferem.

Os estudos indicados são feitos tanto a partir da leitura e análise de decisões judiciais quanto dos perfis dos julgadores ${ }^{85}$, sendo intensificados, principalmente a partir de 2002, após a criação da TV Justiça. Tal inferência é possível a partir de observação cronológica aos trabalhos que fazem referência ao estudo e aprofundamento de um possível processo decisório dos ministros do STF. Com raríssimas exceções, grande parte dos estudos foi realizada após a inauguração da transmissão ao vivo das sessões de julgamento no plenário do STF. Isso porque, o cenário proporcionado pela TV Justiça estimula o caráter opinativo daqueles que a assistem a partir das decisões que os ministros proferem e constantes discussões protagonizadas por eles.

O mais importante a ser destacado é que a resposta à pergunta "como os juízes decidem?" é buscada por aqueles que empenham um esforço intelectual em objetificar ações dos julgadores que compõem o colegiado no STF a partir principalmente da leitura de decisões judiciais e

${ }^{82}$ Cf. LEWANDOWSKI, Andressa. Processos decisórios no Supremo Tribunal Federal. Anais do 35ㅜ Encontro Anual da ANPOCS. Caxambu, MG: ANPOCS, 2011.

${ }^{83}$ Como exemplo, é possível citar os casos da "Ficha Limpa" (RE n.ํㅜ 630.147, DF, Rel. Min. Ayres Britto; RE n. 631.102/PA, Rel. Min. Joaquim Barbosa; e RE 633.703/MG, Rel. Min. Gilmar Mendes) e “Mensalão" (AP n.ํ4ㅇ, Rel. Min. Joaquim Barbosa). ${ }^{84}$ Com exemplo, é possível citar a tese jurídica defendida pelo Min. Gilmar Mendes em voto proferido nos autos da Recl. 4335-5/AC, sob a argumentação de necessidade de reconhecimento de autêntica mutação constitucional do art. 52, X, da Constituição Federal. Para o Ministro, o referido dispositivo tem, atualmente, sentido de apenas atribuir publicidade às decisões proferidas pelo Supremo Tribunal Federal, em se tratando de controle difuso. Por consequência, haveria uma aproximação das diferentes espécies de controle de constitucionalidade existentes no sistema brasileiro: difuso e abstrato, permitindo, então, que, de acordo com a tese defendida pelo Ministro Gilmar, as decisões proferidas pelo plenário do Supremo Tribunal Federal, mesmo em se tratando de controle difuso de constitucionalidade, sejam dotadas de efeitos erga omnes e vinculantes.

${ }^{85}$ Cf. OLIVEIRA, Fabiana Luci de. O Supremo Relator: Processo Decisório e mudanças na composição do STF nos Governos FHC e Lula. Revista Brasileira de Ciências Sociais, Vol. 27, 80, 2012; e OLIVEIRA, Fabiana Luci de. Processo Decisório no Supremo Tribunal Federal: Coalizões e "Panelinhas". Revista de Sociologia Política, Vol. 20, 44, 2012. 
transmissão ao vivo das sessões de julgamento ocorridas no plenário. $\mathrm{O}$ caminho percorrido passa (i) pelo enfoque nas deliberações, a fim de identificar ações passíveis de serem objetificadas; (ii) pela incorporação de modelos explicativos importados da teoria política, que permitam aprofundar estudo e compreensão do direito constitucional; (iii) até alcançar uma identificação ou criação de diferentes perfis de julgadores.

De fato, há ao menos uma semelhança dentre os estudos mencionados neste tópico: todos reivindicam um potencial explicativo das cortes constitucionais a partir do enfoque em seus julgadores, mais especificamente no momento em que se reúnem para deliberar. Consequentemente, é de se notar que nenhum dos estudos que tem se tornado referência sobre análise do processo decisório buscam investigar como os juízes decidem a partir do enfoque em julgadores singulares ou colegiados de segunda instância. Essa opção, por empenhar esforços explicativos acerca do processo de deliberação das cortes constitucionais, e consequentemente traçar um perfil do órgão julgador antecipando possíveis posicionamentos sobre determinadas matérias, demonstra novamente um movimento de empoderamento de um argumento pela doutrina jurídica ao se aproximar do discurso apropriado pelo direito constitucional.

Decisões judiciais sobre temas de grande repercussão social, categorias constitucionais elevadas ao status de garantias ou princípios, a maior visibilidade da corte constitucional no cenário político, dentre outros, representam elementos utilizados por uma movimentação doutrinária em fortalecer seus argumentos perante a comunidade com que dialogam. A incorporação do discurso constitucional a um argumento desenvolvido, além de objetivar maior força e credibilidade, permite uma ampliação de interlocutores para aquele que profere o discurso e desenvolve o argumento. E esse é um fenômeno não exclusivo à linha investigativa abordada no presente tópico. Outros atores começam a se movimentar para apropriar o discurso constitucional às suas linhas de pesquisa.

Diferentemente do diálogo estabelecido entre teoria política e direito constitucional por aqueles que fazem análise do processo decisório, cientistas sociais e até mesmo juristas em relação maior com a antropologia buscam também uma imersão no campo jurídico ${ }^{86}$ por meio inclusive da realização de pesquisas etnográficas. O objetivo de tal aproximação pode ser compreendido a partir das palavras de Luiz Eduardo Abreu ao escrever o texto "Etnografia constitucional":

${ }^{86}$ Cf. BOURDIEU, Pierre. O Poder Simbólico. $2^{\underline{a}}$ ed. Rio de Janeiro, RJ: Bertrand Brasil, 1998.

3 JOURNAL OF INSTITUTIONAL STUDIES 1 (2017) 
A ideia é, portanto, levar em consideração não apenas a sistematização dogmática das normas jurídicas, mas principalmente o detalhe, a maneira como, de fato, as regras e os princípios jurídicos se reproduzem no cotidiano, onde as grandes questões (como a legitimidade, a justiça e os valores) talvez deem lugar a questões de ordem mais pragmática, como a ocupação de posições nos respectivos campos sociais (BOURDIEU, 1998) ou o uso das palavras e dos instrumentos jurídicos para propósitos contextuais, como, $\mathrm{p}$. ex., tentar ganhar tempo no processo de cassação de um mandato parlamentar, enquanto se tenta criar as condições políticas necessárias para ganhar o voto da maioria em plenário. O que está em jogo aqui é uma mudança de perspectiva: sair da elaboração um tanto abstrata de fórmulas universais e entrar no universo não tão asséptico, mas, para mim pelo menos, muito mais interessante do uso real dos argumentos e da sua construção social. ${ }^{87}$

Desse modo, diferentes atores têm buscado no direito constitucional a apropriação de um discurso capaz não apenas de legitimar seu argumento e empoderá-lo, mas de ampliar os seus interlocutores e acirrar a disputa no campo jurídico sobre "o que é dito" e "como é dito". ${ }^{88}$ Os tópicos anteriores demonstraram exemplos da caracterização deste conflito aqui evidenciado, como na construção da ideia da colegialidade, como ela é fundamentada e elevada ao status constitucional e discutida por outras áreas do saber como forma de aproximação e apropriação ao discurso constitucional. $\mathrm{O}$ tópico seguinte abordará tais questões de modo a deixar mais claro o argumento até aqui construído.

\section{CONSIDERAÇÕES FINAIS: QUANDO A IDEOLOGIA VIRA DOGMA E O DOGMA UM PRINCÍPIO}

O presente texto teve por objetivo elaborar uma arqueologia conceitual acerca da colegialidade. Por seu intermédio, foi possível verificar que o direito brasileiro reivindica uma apropriação da colegialidade do sistema jurídico italiano, sob o fundamento de correção

${ }^{87}$ ABREU, Luiz Eduardo. Etnografia Constitucional: quando o Direito encontra a Antropologia. In: Luis Eduardo Abreu (Org.). Os bastidores do Supremo e outras histórias curiosas: 5 estudos de etnografia constitucional. Brasília, DF: UniCEUB, 2013, p. 17.

${ }^{88}$ Cf. BOURDIEU, Pierre. O Poder Simbólico. $2^{\underline{a}}$ ed. Rio de Janeiro, RJ: Bertrand Brasil, 1998.

3 JOURNAL OF INSTITUTIONAL STUDIES 1 (2017) 
das decisões judiciais proferidas pelos juízos singulares devido o potencial cometimento de injustiças do ser humano. Por estes motivos, a colegialidade estaria relacionada a um conjunto de magistrados que reapreciaria a decisão já proferida pelo magistrado de primeira instância. O fundamento atribuído pelos autores brasileiros à colegialidade, como o fim político da decisão, o cometimento de injustiças, dentre outros, permitiu a identificação da colegialidade enquanto uma ideologia proveniente do sistema recursal. Enquanto uma ideologia recursal, a doutrina clássica do direito processual civil brasileiro construiu o argumento de que a pluralidade de julgadores geraria uma hierarquia entre a primeira e segunda instância, devido a possibilidade de um número de magistrados superior ao que proferiu a decisão recorrida melhor analisar o mérito da causa.

Posteriormente, identificou-se que a doutrina clássica brasileira se referia constantemente à doutrina italiana do processo civil para fundamentar a colegialidade e reivindicar uma proximidade entre os sistemas jurídicos brasileiro e italiano. A partir disso, foi feita uma consulta à doutrina italiana sobre o tema da colegialidade, a fim investigar a proximidade ao menos do sistema recursal, reivindicada por autores brasileiros. E tendo acesso à literatura italiana sobre o tema, com referência aos principais autores italianos citados por brasileiros, confirmou-se que a colegialidade estava associada ao sistema recursal, mas sob fundamento diverso. No direito processual civil italiano, a colegialidade é fundamentada na oralidade, o que contribuiu à identificação de alguns distanciamentos à colegialidade no Brasil.

A partir do aprofundamento da oralidade, percebeu-se que o direito brasileiro incorporou a ideia da colegialidade do direito italiano, mas sem importar categorias fundamentais à sua compreensão e funcionamento, como a discussão oral do mérito da causa e a deliberação secreta. Essas categorias são responsáveis por imprimir uma dinâmica ao órgão colegiado italiano diferente da existente no colegiado brasileiro, onde a discussão oral do mérito é mitigada e a deliberação é pública. Apesar de as distinções serem visíveis, merece destaque o fato de a colegialidade, após se fundamentar enquanto uma ideologia, se consolida no raciocínio jurídico ${ }^{89} \mathrm{o}$ jurídico como uma categoria fundamental ao sistema recursal brasileiro.

A ideia da colegialidade foi completamente aceita pela comunidade jurídica, chegando-se a convencionar entre os autores brasileiros tratar-se de uma regra. A colegialidade nos tribunais passou a ser considerada

${ }^{89}$ Cf. SCHAUER, Frederick. Thinking like a Lawyer: a new introduction to Legal

Reasoning. Cambridge, MA: Harvard University Press, 2009.

3 JOURNAL OF INSTITUTIONAL STUDIES 1 (2017) 
característica básica do sistema jurídico brasileiro. Mesmo no período identificado como havendo um déficit de textos escritos sobre o tema, a colegialidade não foi extinta ou até mesmo mitigada. $\mathrm{O}$ modelo criado para revisar decisões judiciais de juízos singulares tornou-se avesso a quaisquer tipos de questionamentos devido a superioridade do número de julgadores a apreciar a decisão recorrida, prevalecendo o jargão "duas cabeças pensam sempre melhor que uma".

Ao ser considerada um dogma, a categoria da colegialidade volta a ser discutida a partir de um possível esvaziamento de suas funções com o aumento dos poderes do relator. Algumas modificações legislativas permitiram que o relator do processo ou recurso resolvesse a questão judicial envolvida antes mesmo da sua submissão ao colegiado. É possível pensarmos inclusive que o agravo interno, que é uma figura criada para recorrer da decisão do relator e finalmente submetê-la ao colegiado, representaria uma tentativa de preservação ao dogma da colegialidade, demonstrando que o objetivo das modificações legislativas não era esvaziar a sua competência até se inverter a lógica do sistema recursal para o julgamento singular ou monocrático.

Entretanto, autores do processo civil viram mais que um possível questionamento ao dogma da colegialidade nessas medidas, enxergando uma violação cada vez maior à categoria. Iniciou-se, assim, um debate relacionando as medidas legislativas e a colegialidade como um campo de disputa pelo "o que é dito" e "como é dito". Segundo Pierre Bourdieu, "o campo jurídico é o lugar de concorrência pelo monopólio do direito de dizer o direito (...)" ${ }^{\prime 9}{ }^{90} \mathrm{E}$ os juristas que escreviam à época, em sua grande maioria advogados e juízes aposentados não satisfeitos com as possíveis mudanças no sistema recursal brasileiro, que estaria deixando de ser colegiado para se tornar monocrático, passam a se apropriar do discurso constitucional a fim de elevar categorias supostamente violadas a um status constitucional e reivindicá-las enquanto princípios.

Ao se referir à disputa no campo jurídico como sendo uma organização social da produção do conhecimento, da ação dos atores e da sua reprodução, Bourdieu destaca como essa dinâmica pode se operar:

As práticas e os discursos jurídicos são, com efeito, produto do funcionamento de um campo cuja lógica específica está duplamente determinada: por um lado, pelas relações de força específicas que lhe conferem a sua estrutura e que orientam as lutas de concorrência ou, mais precisamente, os conflitos de competência que nele têm lugar e, por outro lado, pela lógica interna das obras

${ }^{90}$ BOURDIEU, Pierre. O Poder Simbólico. 2a ed. Rio de Janeiro, RJ: Bertrand Brasil, 1998, p. 212. 
jurídicas que delimitam em cada momento o espaço dos possíveis e, deste modo, o universo das soluções propriamente jurídicas. ${ }^{91}$

Por fim, relacionando o espaço de disputas destacado por Bourdieu com o que até agora foi construído, é possível perceber uma mobilização da doutrina jurídica em elevar a categoria da colegialidade a um princípio constitucional, sob o argumento de uma possível constitucionalização do processo civil. ${ }^{92}$ No entanto, essa mobilização doutrinária equivaleria tão somente a empoderar um argumento por meio do empenho de um trabalho intelectual específico ao elevar uma determinada categoria jurídica a princípio constitucional. Assim, a categoria elevada a "princípio constitucional" é colocada em posição hierarquicamente superior, dentro do debate, às categorias nativas no direito. Assim, a construção da autoridade do argumento no direito passa por um processo de elevação de status a partir da apropriação de discursos que o torne hierarquicamente superior, construído principalmente em um ambiente de disputas em que os atores reivindiquem o direito de dizer como a própria realidade social funciona.

\section{REFERÊNCIAS}

ABREU, Luiz Eduardo. Etnografia Constitucional: quando o Direito encontra a Antropologia. In: Luis Eduardo Abreu (Org.). Os bastidores do Supremo e outras histórias curiosas: 5 estudos de etnografia constitucional. Brasília, DF: UniCEUB, 2013.

ALVIM, José Eduardo Carreira. Novo Agravo. $4^{\underline{a}}$ ed. Rio de Janeiro, RJ: Forense, 2002.

AMARAL, Oswaldo Pinto do. Código de Processo Civil Brasileiro Comentado, Volume V: Arts. 808 a 1052. São Paulo, SP: Livraria

${ }^{91}$ BOURDIEU, Pierre. O Poder Simbólico. $2^{\underline{a}}$ ed. Rio de Janeiro, RJ: Bertrand Brasil, 1998, p. 211.

${ }^{92}$ Cf. BOURDIEU, Pierre. O Poder Simbólico. $2^{a}$ ed. Rio de Janeiro, RJ: Bertrand Brasil, 1998. 
Acadêmica/Saraiva \& Cia Editores, 1941.

AMERICANO, Jorge. Comentários ao Código de Processo Civil do Brasil, Volume IV. São Paulo, SP: Livraria Acadêmica/Saraiva \& Cia Editores, 1943.

ARGUELHES, Diego Werneck; RIBEIRO, Leandro Molhano. As indicações presidenciais para o Supremo Tribunal Federal e seus fins políticos: uma resposta a Mariana Prado e Cláudia Turner. Revista de Direito Administrativo - RDA, Vol. 255, 2010.

BAUTISTA, José Becerra. El Proceso Civil em México. $4^{\text {a }}$ ed. Ciudad del México: Editorial Porrúa, 1974.

BENETI, Sidnei. Monocratismo, monologuismo e colegialidade nos tribunais. In: Jorge Mussi; Luiz Felipe Salomão; Napoleão Nunes Maia Filho (Org.). Estudos Jurídicos em Homenagem ao Ministro Cesar Asfor Rocha, Vol. III. Ribeirão Preto, SP: Migalhas, 2012.

BOURDIEU, Pierre. O Poder Simbólico. $2^{\mathrm{a}}$ ed. Rio de Janeiro, RJ: Bertrand Brasil, 1998.

CAPPELLETTI, Mauro. Processo e Ideologie. $2^{a}$ ed. Bologna: Il Mulino Editrice, 1969.

CAPPELLETTI, Mauro; GARTH, Bryant. Acesso à Justiça. Trad. Ellen Gracie Northfleet. Porto Alegre, RS: Sergio Antonio Fabris Editor, 1988.

CARVALHO SANTOS, João Manuel de. Código de Processo Civil Interpretado, Volume IX. Rio de Janeiro, RJ: Freitas Bastos, 1941.

CHIOVENDA, Guiseppe. Principii di Diritto Processuale Civile: le azioni, il processo di cognizione. $3^{\underline{a}}$ ed. Napoli: N. Jovene, 1923. 
COUTINHO, Diogo R.; VOJVODIC, Adriana de Moraes (Orgs.). Jurisprudência Constitucional: Como Decide o STF? São Paulo, SP: Malheiros/SBDP, 2009.

DE PLACIDO E SILVA. Comentários ao Código de Processo Civil. Curitiba, PR: Guaíra, 1940.

DE SETA, Cristina Gomes Campos. “Vistos, relatados e discutidos estes autos, acordam os Ministros do Supremo Tribunal Federal"... Mas, há consenso na construção das decisões do Supremo Tribunal Federal? Tese (Doutorado em Direito), Programa de Pós-Graduação em Direito, Universidade Gama Filho, 2012.

DIDIER JR., Fredie; CUNHA, Leonardo José Carneiro da. Curso de Direito Processual Civil, Vol. 3: Meios de Impugnação às Decisões Judiciais e Processos nos Tribunais. $5^{\mathrm{a}} \mathrm{ed}$. Salvador, BA: JusPODIVM, 2008.

DINAMARCO, Cândido Rangel. O relator, a jurisprudência e os recursos. In: Tereza Arruda Alvim Wambier; Nelson Nery Jr. (Orgs.). Aspectos polêmicos e atuais dos Recursos Cíveis de acordo com a Lei 9.756/98. São Paulo, SP: Revista dos Tribunais, 1999.

FONTAINHA, Fernando; HARTMANN, Ivar; CORRÊA, Ana Maria Macedo; ALVES, Camila; PITASSE, Katarina. Metodologia da Pesquisa. Rio de Janeiro, RJ: FGV Direito RIO, 2014. Disponível em: < $<$ https://direitorio.fgv.br/sites/direitorio.fgv.br/files/u100/tcc metodologia da pesquisa 2014-2.pdf $>$. Acesso em: 09 de agosto de 2017.

GRECO, Leonardo. Estudos de Direito Processual. Campos dos Goytacazes, RJ: Ed. Faculdade de Direito, 2005.

LEWANDOWSKI, Andressa. Processos decisórios no Supremo Tribunal 
Federal. Anais do $35^{\circ}$ Encontro Anual da ANPOCS. Caxambu, MG: ANPOCS, 2011.

LIEBMAN, Enrico Tullio. Manuale di Diritto Processuale Civile, Volume II. Milano: Giuffrè, 1959.

LIMA, Alcides de Mendonça. Introdução aos Recursos Cíveis. $2^{\underline{a}}$ ed. São Paulo, SP: Revista dos Tribunais, 1976.

MANDRIOLI, Crisanto. Corso di Diritto Processuale Civile, 2: Il Processo di Cognizone. Torino: G. Giappichelli, 1975.

McCANN, Michael. Rights at Work: Pay Equity Reform and Politics of Legal Mobilization. Chicago, IL: The University of Chicago Press, 1994.

MELLO, Isabelle de Matos Pereira de. Magistrados a serviço do Rei: a administração da Justiça e os ouvidores gerais na comarca do Rio de Janeiro (1710-1790). Tese (Doutorado em História Social), Programa de Pós-Graduação em História Social, Universidade Federal Fluminense, Niterói, 2013.

MENDES, Conrado Hübner. Constitutional Courts and Deliberative Democracy. Oxford: Oxford University Press, 2013.

. Onze Ilhas. Folha de São Paulo: Tendências e Debates, São

Paulo, SP, 01 fev. 2010.

MONTEIRO, João. Teoria do Processo Civil, Vol. II. $6^{\underline{a}}$ ed. Rio de Janeiro, RJ: Borsoi, 1956.

MONTESANO, Luigi; ARIETA, Giovanni. Diritto Processuale Civile, 2: La Cognizione di Rito Ordinario. Torino: G. Giappichelli, 1994.

MOREIRA, José Carlos Barbosa. Algumas inovações da Lei 9.756 em 
matéria de Recursos Cíveis. In: Tereza Arruda Alvim Wambier; Nelson Nery Jr. (Orgs.). Aspectos polêmicos e atuais dos Recursos Cíveis de acordo com a Lei 9.756/98. São Paulo, SP: Revista dos Tribunais, 1999.

. Comentários ao Código de Processo Civil, Volume V. 8a ed. Rio de Janeiro, RJ: Forense, 2000.

MORTARA, Lodovico. Manuale della Procedura Civile, Volume 1. $5^{\text {a }}$ ed. Torino: Unione Tipografico-Editrice, 1906.

OLIVEIRA, Fabiana Luci de. O Supremo Relator: Processo Decisório e mudanças na composição do STF nos Governos FHC e Lula. Revista Brasileira de Ciências Sociais, Vol. 27, 80, 2012.

. Processo Decisório no Supremo Tribunal Federal: Coalizões e

"Panelinhas". Revista de Sociologia Política, Vol. 20, 44, 2012.

OLIVEIRA, José Aparecido de; EPSTEIN, Isaac. Tempo, Ciência e Consenso: os diferentes tempos que envolvem a Pesquisa Científica, a Decisão Política e a Opinião Pública. Interface (Botucatu):

Communication, Health, Education, Vol. 13, 29, 2009.

PONTES DE MIRANDA. Comentários ao Código de Processo Civil, Tomo I. Rio de Janeiro, RJ: Forense, 1947.

. Comentários ao Código de Processo Civil, Tomo I. $2^{a}$ ed. Rio de Janeiro, RJ: Forense, 1958.

. Comentários ao Código de Processo Civil, Tomo II. $2^{\mathrm{a}}$ ed. Rio de Janeiro, RJ: Forense, 1960.

TÜRNER, Claudia; PRADO, Mariana. A Democracia e o seu impacto nas nomeações dos Diretores das Agências Reguladoras e Ministros do STF. Revista de Direito Administrativo - RDA, No. 250, 2009. 
REDENTI, Enrico. Derecho Procesal Civil, Tomo I. Trad. Santiago Sentis Melendo e Marino Ayerra Redin. Buenos Aires: Ediciones Juridicas Europa-America, 1957.

RIBEIRO, Leandro Molhano; ARGUELHES, Diego Werneck.

Preferências, Estratégias e Motivações: pressupostos institucionais de teorias sobre comportamento judicial e sua transposição para o caso brasileiro. Revista Direito e Práxis, Vol. 4, 2, 2013.

SCHAUER, Frederick. Thinking like a Lawyer: a new introduction to Legal Reasoning. Cambridge, MA: Harvard University Press, 2009.

SILVA, Virgílio Afonso da. O STF e o Controle de Constitucionalidade: Deliberação, Diálogo e Razão Pública. Revista de Direito Administrativo - RDA, No. 250, 2009.

. Deciding Without Deliberating. International Journal of Constitutional Law, Vol. 11, 3, 2013.

TEIXEIRA DE FREITAS, Augusto. Consolidação das Leis Civis. $3^{\underline{a}}$ ed. Rio de Janeiro, RJ: B. L. Garnier, 1876.

VITERBO, Mario Casarino. Manual de Derecho Procesal: Derecho Procesal Orgánico, Tomo II. 2ª ed. Santiago: Editorial Jurídica de Chile, 1970.

VOJVODIC, Adriana de Moraes; MACHADO, Ana Mara França;

CARDOSO, Evorah Lusci Costa. Escrevendo um Romance, Primeiro Capítulo: Precedentes e Processo Decisório no STF. Revista Direito GV, Vol. 5, 1, 2009. 
A Colegialidade nos Tribunais: quando uma Ideologia vira Dogma e o Dogma um Princípio The Collegiality in the Courts: when an Ideology becomes Dogma and the Dogma becomes a Principle Submetido em: 2017-04-20 Aceito em: 2017-07-29 